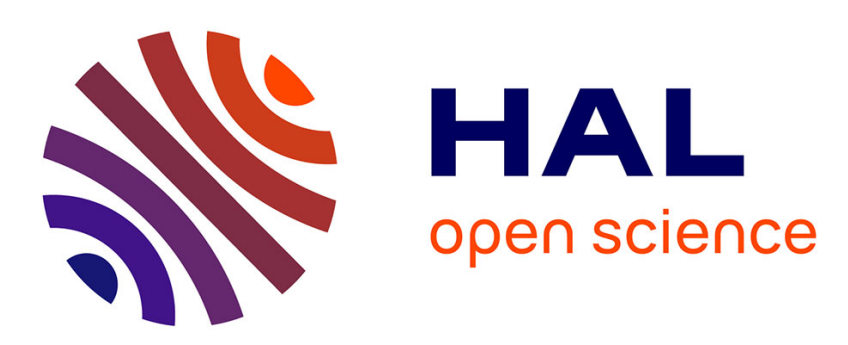

\title{
Modeling of Water-rock interaction in the Mackenzie Basin: competition between sulfuric and carbonic acids
}

\author{
Yves Godderis, Emilie Beaulieu, David Labat, Caroline Roelandt, Jérôme
} Gaillardet, Damien Calmels

\section{- To cite this version:}

Yves Godderis, Emilie Beaulieu, David Labat, Caroline Roelandt, Jérôme Gaillardet, et al.. Modeling of Water-rock interaction in the Mackenzie Basin: competition between sulfuric and carbonic acids. Chemical Geology, 2011, 289, pp.114-123. 10.1016/j.chemgeo.2011.07.020 . hal-00665395

\section{HAL Id: hal-00665395 \\ https://hal.science/hal-00665395}

Submitted on 1 Feb 2012

HAL is a multi-disciplinary open access archive for the deposit and dissemination of scientific research documents, whether they are published or not. The documents may come from teaching and research institutions in France or abroad, or from public or private research centers.
L'archive ouverte pluridisciplinaire HAL, est destinée au dépôt et à la diffusion de documents scientifiques de niveau recherche, publiés ou non, émanant des établissements d'enseignement et de recherche français ou étrangers, des laboratoires publics ou privés. 


\section{Accepted Manuscript}

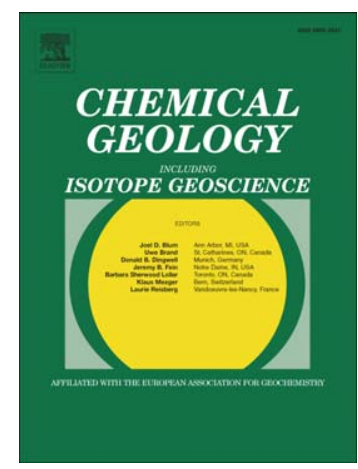

Modeling of Water-rock interaction in the Mackenzie Basin: competition between sulfuric and carbonic acids

E. Beaulieu, Y. Goddéris, D. Labat, C. Roelandt, D. Calmels, J. Gaillardet

PII: $\quad$ S0009-2541(11)00308-1

DOI: $\quad$ doi: $10.1016 /$ j.chemgeo.2011.07.020

Reference: $\quad$ CHEMGE 16281

To appear in: $\quad$ Chemical Geology

Received date: $\quad 10$ May 2011

Revised date: $\quad 13$ July 2011

Accepted date: 24 July 2011

Please cite this article as: Beaulieu, E., Goddéris, Y., Labat, D., Roelandt, C., Calmels, D., Gaillardet, J., Modeling of Water-rock interaction in the Mackenzie Basin: competition between sulfuric and carbonic acids, Chemical Geology (2011), doi: 10.1016/j.chemgeo.2011.07.020

This is a PDF file of an unedited manuscript that has been accepted for publication. As a service to our customers we are providing this early version of the manuscript. The manuscript will undergo copyediting, typesetting, and review of the resulting proof before it is published in its final form. Please note that during the production process errors may be discovered which could affect the content, and all legal disclaimers that apply to the journal pertain. 
Modeling of Water-rock interaction in the Mackenzie Basin: competition between sulfuric and carbonic acids.

E. Beaulieu ${ }^{1}$, Y. Goddéris ${ }^{1}$, D. Labat ${ }^{1}$, C. Roelandt ${ }^{2}$, D. Calmels ${ }^{3}$, J. Gaillardet $^{3}$

${ }^{1}$ Géoscience Environnement Toulouse (GET), CNRS-Université de Toulouse, Observatoire Midi-Pyrénées, 31400 Toulouse, France (beaulieu@get.obs-mip.fr)

${ }^{2}$ Geophysical Institute, University of Bergen, Norway

${ }^{3}$ Laboratoire de Géochimie et Cosmochimie, Institut de Physique du Globe de Paris, Sorbonne Paris Cité, Univ Paris Diderot, UMR 7154 CNRS, F-75005 Paris, France 


\section{Abstract :}

The chemical weathering of continental surfaces depends on many factors including lithology, climate, tectonics, erosion, soil or vegetation, and also on the availability of acidity in the weathering zone. In addition to atmospheric/soil $\mathrm{CO}_{2}$, sulfide oxidation may represent a significant source of protons for weathering reactions as shown previously for the rivers draining the Mackenzie Basin, Canada. Here, a numerical model describing continental weathering reactions based on laboratory kinetic laws is coupled to a dynamic global vegetation model (the B-WITCH model) in order to estimate the impact of sulfide oxidation on chemical weathering and associated atmospheric $\mathrm{CO}_{2}$ consumption fluxes throughout the Mackenzie River basin. The model is first calibrated with available field data for the various sub-basin of the Mackenzie watershed and then, a simulation is performed removing the contribution of sulfuric acid to the weathering system. The main outcomes of the present study are that 1) the dissolved silica export is controlled by secondary minerals reactivity in soils and the calcium and magnesium fluxes are driven by the dissolution of calcite and dolomite, 2) the atmospheric $\mathrm{CO}_{2}$ consumption by weathering processes in the Mackenzie river is limited, accounting for only $24 \%$ of the total bicarbonate flux to the ocean, confirming a previous study and suggesting that weathering processes in the Mackenzie watershed acts as a source of carbon to the atmosphere at the geological timescale, and 3) the presence of sulfide minerals within a river basin decreases the apparent net consumption of atmospheric $\mathrm{CO}_{2}$ through chemical weathering. We show that the actual production of sulfuric acid in the weathering zone of the Mackenzie basin reduces the net atmospheric $\mathrm{CO}_{2}$ consumption by about two, compared to what the atmospheric $\mathrm{CO}_{2}$ consumption should be in the absence of sulfide minerals. Sulfuric-acid-driven chemical weathering has thus to be considered at both short and long timescales when looking at the link between chemical weathering and the global carbon cycle. 
Keywords : weathering, silicate, $\mathrm{CO}_{2}$ consumption, carbonate, sulfide oxidation

\section{Introduction :}

The relationship between climate and chemical weathering of the continental surfaces is complex. Walker et al. (1981) proposed that a negative feedback between the chemical weathering rate of silicate minerals and climate regulates the atmospheric $\mathrm{CO}_{2}$ concentration in the atmosphere and so maintains climate stability throughout Earth's history. Any increase in the atmospheric $\mathrm{CO}_{2}$ partial pressure leads to warmer global temperature and to an acceleration of the hydrologic cycle. The subsequent enhanced rainfall promotes faster $\mathrm{CO}_{2}$ consumption by chemical weathering of silicate rocks, which in turn buffers the increase in atmospheric $\mathrm{CO}_{2}$ concentration. Always considered in long term climate studies (Berner et al., 1983 ; Berner and Kothavala, 2001 ; Donnadieu et al., 2006 ; Goddéris and François, 1995 ; Goddéris et al., 2003 ; Walker et al., 1981 ; Wallmann, 2001) the question whether this negative climatic loop is active at much shorter timescale (decadal to centennial) has been recently stressed (Gislason et al., 2009). Because of this shrinkage of the timescale of interest, carbonate weathering has to be taken into account as it also consumes atmospheric $\mathrm{CO}_{2}$ at timescale typically below a few 100 kyr. However, the link between climate and continental weathering appears to be much more complex than initially proposed by Walker et al. (1981). 
Weathering rates depend on many factors such as the mineralogy of the rocks exposed (Amiotte-Suchet et al., 2003 ; Dessert et al., 2001), the aging of the surfaces (Navarre-Sitchler and Brantley, 2007), the behavior of clay mineral phases (Goddéris et al., 2006 ; Maher et al., 2009 ; Violette et al., 2010), the presence of carbonate phases (Goddéris et al., 2010), the supply of water and its residence time in soils, the $\mathrm{pH}$ (Oliva et al, 2003), the temperature of the soil solutions (White and Blum, 1995), the physical erosion (Gaillardet et al., 1999; West et al., 2005) and the vegetation (Moulton et al., 2000). Constraining all those parameters is a major challenge in Earth surface geochemistry.

Another still unsolved problem is the contribution of other acids than carbonic acid to chemical weathering. Indeed, sulfide oxidation commonly occurs in watershed, releasing sulfuric acid and hence protons available for weathering. Several studies have shown the need for considering sulfide oxidation and subsequent dissolution of rocks when dealing with the $\mathrm{CO}_{2}$ consumption budget by chemical weathering in a watershed (Anderson et al., 2000 ; Calmels et al., 2007; Gaillardet et al., 2003 ; Galy and France-Lanord, 1999; Hercod et al., 1998; Millot et al., 2003; Lerman et al., 2007; Li et al., 2008; Spence and Telmer, 2005). Indeed, once exposed at the surface by erosional processes, pyrite is oxidized producing sulfuric acid (Eq. 1) that promotes the dissolution of carbonates without consuming atmospheric $\mathrm{CO}_{2}$ (Eq. 2).

$$
\begin{aligned}
& \mathrm{FeS}_{2}+15 / 4 \mathrm{O}_{2}+7 / 2 \mathrm{H}_{2} \mathrm{O} \rightarrow \mathrm{Fe}(\mathrm{OH})_{3}+2 \mathrm{H}_{2} \mathrm{SO}_{4} \\
& 2 \mathrm{CaCO}_{3}+\mathrm{H}_{2} \mathrm{SO}_{4} \rightarrow 2 \mathrm{Ca}^{2+}+2 \mathrm{HCO}_{3}^{-}+\mathrm{SO}_{4}^{2-}
\end{aligned}
$$

The released dissolved bicarbonates are transported to the oceans by rivers. Once reaching the ocean, carbonate minerals can precipitate, releasing one mole of $\mathrm{CO}_{2}$ to the atmosphere for each mole of $\mathrm{CaCO}_{3}$ accumulated on the seafloor. At a timescale below the residence time of sulfur in the ocean (about $10 \mathrm{Myr}$ ), the dissolution of carbonate rocks by sulfuric acid thus results in the release of $\mathrm{CO}_{2}$ to the atmosphere. As a consequence, the amount of atmospheric 
$\mathrm{CO}_{2}$ consumed during chemical weathering is reduced when sulfuric acid is involved, and thus the drawdown of $\mathrm{CO}_{2}$ by weathering can be overestimated when the role of sulfide oxidation is ignored (Calmels et al., 2007; Spence and Telmer, 2005). The reaction between sulfuric acid and silicate minerals also occurs, however it is less probable because of the lowest reactivity of silicates compared to carbonates (Anderson et al., 2000).

Recent studies have estimated the bicarbonate flux into the ocean released by the reaction between sulfuric acid and carbonate rocks. For instance, those studies calculated that $46 \%$, $63 \%$ and $62 \%$ of the bicarbonate exported by the Nass and Skeena Rivers, Western Cordillera, Canada (Spence and Telmer, 2005), the Beipanjiang River, China, (Li et al., 2008) and the Mackenzie River (Calmels et al., 2007), respectively, was ancient carbon originating from carbonate rocks as a result of of sulfuric-acid weathering.

The present study explores for the first time the role of sulfuric acid-promoted weathering on the weathering budget of a continental-scale watershed through numerical modeling. The study site is the Mackenzie river catchment. We first calibrate the numerical model on its present-day state using available field data. Then, a simulation is performed removing the contribution of sulfuric acid in the model, allowing the quantification of the role of pyrite oxidation on the weathering and $\mathrm{CO}_{2}$ consumption budgets at continental scale.

\section{Setting:}

The Mackenzie River basin is located in northwestern Canada and subjected to arctic and subarctic climatic conditions. It is one of the largest arctic river system with an area of 1.8 million $\mathrm{km}^{2}$, representing one-fifth of the total land area of Canada. The mean water discharge is $9700 \mathrm{~m}^{3} / \mathrm{s}$ (Louie et al., 2002 ; Millot et al., 2003). The mean annual rainfall is equal to 421 $\mathrm{mm}$ (Louie et al., 2002), and the resulting mean annual surface runoff is $170 \mathrm{~mm}$. Consequently, the mean annual evapotranspiration of the Mackenzie watershed is rather low 
at $250 \mathrm{~mm}$ (Louie et al., 2002 ; Stewart et al., 1998), and mainly occurs between May and October. The mean annual temperature is equal to $-3.4^{\circ} \mathrm{C}$. The vegetal cover varies from boreal forests (coniferous, broadleaf and mixed forests) in the south to alpine forests in the Rocky mountains and artic tundra in the northern part of the basin (Natural Ressources Canada, 1993).

From East to West, the Mackenzie basin can be divided into three major physiographic regions : the Canadian Shield, the Interior Platform and the Rocky Mountains (fig. 1). The Canadian Shield consists of a myriad of lakes and valley-wetlands separating upland outcrops of Precambrian bedrock; the interior Plains are covered by wetlands, lakes and the Rockies is a mountainous area with valleys and high plateaus. The lithology of the Mackenzie River basin is composed of $68.3 \%$ of sedimentary rocks (clastics and carbonates), $29.2 \%$ of non sedimentary rocks (igneous and metamorphic rocks) and $2.5 \%$ of evaporites (halite and gypsum) (Reeder et al., 1972). A large portion of the watershed is underlined by a discontinuous permafrost. The permafrost starts at depth of 0.3 to $1.0 \mathrm{~m}$ and can be as thick as $500 \mathrm{~m}$ over much of the northern part of the watershed (Natural Ressources Canada, 1995).

The Mackenzie watershed can be divided into six subbasins, ie, Peel, Bear, Liard, Slave, Peace and Athabasca (fig. 1; Louie et al., 2002), three great lakes (Great Bear Lake, Great Slave Lake and Athabasca Lake) and three major deltas. Water fluxes (evapotranspiration, surface runoff, precipitation) and temperature vary from one sub-basin to the other. The mean annual evapotranspiration ranges between about $220 \mathrm{~mm} / \mathrm{yr}$ (Peel basin) and $320 \mathrm{~mm} / \mathrm{yr}$ (Athabasca and Peace basins) and the mean annual temperature ranges between $-6.4^{\circ} \mathrm{C}$ (Bear and Peel basins) and $0^{\circ} \mathrm{C}$ (Peace basin) (Louie et al., 2002 ; Van Der Linden and Woo, 2003). The mean annual surface runoff and precipitation are estimated to vary from about $100 \mathrm{~mm} / \mathrm{yr}$ (Slave basin) up to $340 \mathrm{~mm} / \mathrm{yr}$ (Liard basin) and from about 275 (Peel basin) up to $510 \mathrm{~mm} / \mathrm{yr}$ 
(Peace basin), respectively (Louie et al., 2002 ; Prowse et al., 2002 ; Rouse, 2000 ; Van Der Linden and Woo, 2003; Woo and Thorne, 2003 ; Yi et al., 2008).

\section{Modelling :}

\subsection{Description of B-WITCH :}

The B-WITCH model links a numerical model describing the chemical weathering of the continental surfaces model (WITCH) to a dynamic biospheric model (LPJ) (Godderis et al., 2009; Roelandt et al., 2010; Beaulieu et al., 2010). B-WITCH is a cascade model, LPJ feeding the WITCH model. It allows simultaneous calculations of the different components of continental weathering fluxes, terrestrial vegetation dynamics, and carbon and water fluxes. The weathering profile is divided into three layers : one superficial layer (from 0 to $0.5 \mathrm{~m}$ depth), one medium layer (from 0.5 to $1.5 \mathrm{~m}$ depth) and one saprolithic layer (from 1.5 to $2 \mathrm{~m}$ depth), which is assumed rather thin given the boreal conditions and the presence of permafrost. The LPJ model uses monthly climate data recorded over the 1901-2002 period in order to estimate water exchanges between atmosphere, vegetation and soil, and to establish the vegetal cover. Calculated mean annual surficial runoff and deep drainage are then used by the WITCH model. In addition, a numerical module calculates (1) the cation uptake and release by the living and dead biomass based on the primary productivity and the carbon recycling calculated by LPJ for each grid cell, and (2) the below ground partial pressure of $\mathrm{CO}_{2}$. All those physical values are averaged over the last 20 years of the LPJ simulation and injected into the WITCH model as boundary conditions. WITCH then calculates the precipitation/dissolution rates of minerals (appendix A), and the chemical composition of deep drainage and surficial runoff with a spatial resolution of $0.5^{\circ}$ lat $\times 0.5^{\circ}$ long. These two terms are then mixed and summed up over each sub-basin and over the whole watershed to estimate the riverine chemical composition at the river mouth. Because of the spatial 
discretization procedure of the Mackenzie watershed at the model resolution $\left(0.5^{\circ}\right.$ lat $\times 0.5^{\circ}$ long), the modeled surface of the catchment is slightly overestimated at $2.110^{6} \mathrm{~km}^{2}$. This overestimation is related to edge effects along the border of the watershed and along lakes. All specific fluxes will be calculated according to this model surface. WITCH is run for 40 years until steady-state is reached (constant mean annual chemical composition of the soil solutions). Only mean annual output are generated.

\subsection{Data :}

The B-WITCH model uses available database for climate, lithology and soil types to estimate the dissolution/precipitation rates of mineral phases, the chemical composition of the soil solution, the distribution of the vegetation and the water fluxes (deep drainage and surficial runoff). The CRU-TS 2.1 spatial climate dataset provides to LPJ monthly air temperature, precipitation, cloud cover and amount of wet days with a spatial resolution of $0.5^{\circ}$ latitude vs $0.5^{\circ}$ longitude (Mitchell and Jones, 2005 ; New et al., 2000). The soil (textural fraction, bulk density, coarse fraction and porosity) and lithological information required by LPJ and WITCH are taken from the ISRIC-WISE global data set (Batjes, 2005) and a global rock lithology database (Amiotte-Suchet et al., 2003), respectively (fig. 2). The soil type is based on the HWSD dataset (FAO/IIASA/ISRIC/ISS_CAS/JRC, 2008).

The Mackenzie River basin spreads over three main lithologies, ie, shield rocks, carbonates and shales, and eleven main soil types (Appendix B, table B.1). The mineralogical composition of the surface and intermediate layers has been defined according to the soil type and the mineralogical composition of the saprolite (Appendix B). Dolomite has been included in the mineralogical composition in agreement with studies dealing with soil and rock composition in Alberta (Dewis et al., 1972 ; Kohut et al., 1995; Michel, 1986) and Saskatchewan (Rostad, 1975), Canada. Finally, the mineralogical composition of the layer 3 
(saprolitic layer) is taken from Best (2003) except for the shale lithology whose mineralogical composition is taken from Shaw and Weaver (1965) (Appendix B, table B.2).

\subsection{Pyrite dissolution:}

Dissolved sulfate in the river waters of the Mackenzie basin predominantly derives from pyrite oxidation within the shale lithology of the Interior Platform (Calmels et al., 2007) and atmospheric inputs. The input of sulfate through rainfall is variable over the watershed with measured concentrations varying from $0.2 \mu \mathrm{mol} / \mathrm{L}$ to $27 \mu \mathrm{mol} / \mathrm{L}$ (Bertram et al., 1986 ; Hidy, 2003). In the present modeling study, we assume that sulfate in the upper soil layer of the model solely orginates from rainfall (no mineral source) and that the sulfate concentration in rain is constant over the watershed at $10 \mu \mathrm{mol} / \mathrm{l}$. The uncertainty on the sulfate input through rainfall would have a minor impact on the sulfate budget of the watershed as pyrite oxidation is by far the main source of dissolved sulfate (Calmels et al., 2007). The main tributaries of the Mackenzie River are much more concentrated than rainwater with sulfate concentration ranging from $160 \mu \mathrm{mol} / \mathrm{L}$ to $1334 \mu \mathrm{mol} / \mathrm{L}$ (Millot et al., 2003).

Modeling mechanistically the sulfate input from pyrite oxidation is not easy. Pyrite oxidation appears to be strongly dependent on mechanical erosion (Calmels et al., 2007), and modeling accurately such process is challenging, especially at continental scale. To overcome that issue, the B-Witch model has been modified by prescribing a sulfate source to each grid element. Because sulfate originates from the oxidation of pyrite in shales, the additional sulfate is released below soil levels, directly into the deepest horizon (layer 3) of grid elements covered by shales (mainly on the interior platform). The sulfate budget of each subbasin is then calculated and the input of pyrite-derived sulfate is calibrated so that the model sulfate export for each subbasin matches exactly the measured sulfate export. Mathematically speaking, this can be translated as follows: 


$$
\sum_{s u b}\left(R_{1} \cdot\left[S O_{4}^{2-}\right]+D_{3} \cdot\left[S O_{4}^{2-}\right]_{3}\right)=S \cdot\left[S O_{4}^{2-}\right]_{i v e r}
$$

where the sum extents over whole considered subbasin. $R_{l}$ is the surficial runoff $(\mathrm{mm} / \mathrm{yr})$ for each grid cell of the considered subbasin and $D_{3}$ is the deep drainage $(\mathrm{mm} / \mathrm{yr})$ calculated by LPJ (fig. 3). $S$ is the stream discharge at the outlet of the subbasin (namely the sum of the surficial runoff and deep drainage of all grid cells of the subbasin) and $\left[\mathrm{SO}_{4}{ }^{2-}\right]_{\text {river }}$ is the sulfate concentration measured in the main stream. $\left[\mathrm{SO}_{4}{ }^{2-}\right]_{1}$ and $\left[\mathrm{SO}_{4}{ }^{2-}\right]_{3}$ correspond to the sulfate concentration in the upper soil layer (fixed at $10 \mu \mathrm{mol} / \mathrm{l}$ ) and the 'saprolitic' layer 3, respectively.

For grid elements above shales, where pyrite oxidation is assumed to occur, $\left[\mathrm{SO}_{4}{ }^{2-}\right]_{\text {river }}$ is used as a calibration parameter (fig. 4). Equation 3 is then solved for $\left[\mathrm{SO}_{4}{ }^{2-}\right]_{3}$. $\left[\mathrm{SO}_{4}{ }^{2-}\right]_{3}$ is thus set at a constant value for each shale grid element of each subbasin. Potential spatial variability inside shale lithologies of each subbasin is not accounted for, given the lack of constraint.

In addition to sulfate, the B-WITCH model is forced with constant rain composition for $\mathrm{K}^{+}$ (1.4 $\left.10^{-6} \mathrm{~mol} / \mathrm{L}\right), \mathrm{Mg}^{2+}\left(9.110^{-6} \mathrm{~mol} / \mathrm{L}\right), \mathrm{Ca}^{2+}\left(3.1510^{-5} \mathrm{~mol} / \mathrm{L}\right), \mathrm{Na}^{+}\left(1.910^{-5} \mathrm{~mol} / \mathrm{L}\right)$ and $\mathrm{Cl}^{-}$ (6.6 $\left.10^{-6} \mathrm{~mol} / \mathrm{L}\right)$. These concentrations represent the averaged value of available measurements in precipitation and snow collected around the Mackenzie watershed, in Alberta and in the Rocky mountains (Bertram et al., 1986 ; Hidy, 2003).

\section{Results and Discussion:}

\subsection{Reference simulation:}

The modeled mean annual water discharge $\left(9045 \mathrm{~m}^{3} / \mathrm{s}\right)$ for the Mackenzie watershed is very close to the measured one $\left(9700 \mathrm{~m}^{3} / \mathrm{s}\right)$ over the last 40 years (Louie et al., 2002 ; Millot et al., 2003). The mean annual surface runoff and deep drainage calculated by the model range 
between $67 \mathrm{~mm} / \mathrm{yr}$ (Peel basin) and $182 \mathrm{~mm} / \mathrm{yr}$ (Liard basin), and between $23 \mathrm{~mm} / \mathrm{yr}$ (Peel basin) and $86 \mathrm{~mm} / \mathrm{yr}$ (Liard basin), respectively (fig. 5). The mean annual evapotranspiration ranges between $132 \mathrm{~mm} / \mathrm{yr}$ (Peel basin) and $186 \mathrm{~mm} / \mathrm{yr}$ (Athabasca basin) and depends on the spatial distribution of the vegetation established by the LPJ model. The vegetal cover is represented by four plant functional types (PFT) on the Mackenzie basin. The boreal needleleaved evergreen PFTs mainly covers the interior platform whereas the boreal broad-leaved summergreen PFTs covers the Rocky mountains area. The boreal needle-leaved summergreen PFTs predominates in the northern part of the basin. The temperate herbaceous PFTs which could be assimilated to tundra covers the northeast and the northwest of Mackenzie basin.

\subsubsection{Spatial distribution of cation concentrations:}

Riverine concentration for a given species $\left(C_{r i v}\right)$ is calculated as follows :

$$
C_{r i v}=\frac{\sum_{i}\left(R_{1} \cdot C_{1}+D_{r} \cdot C_{3}\right)}{\sum_{i}\left(R_{1}+D_{r}\right)}
$$

where $R_{1}$ is the surficial runoff calculated by LPJ for each grid element, $D_{r}$ is the deep drainage, $C_{1}$ and $C_{3}$ are the concentration of a given species in the surficial soil layer and in the saprolite, respectively (Roelandt et al., 2010). This equation is applied to each major cation, ie, $\mathrm{Ca}^{2+}, \mathrm{Mg}^{2+}, \mathrm{Na}^{+}$and $\mathrm{K}^{+}$. The $\mathrm{Ca}^{2+}, \mathrm{Mg}^{2+}, \mathrm{Na}^{+}$and $\mathrm{K}^{+}$concentrations simulated by the B-WITCH model are compared to the measured concentrations in the major tributaries of the Mackenzie River (Millot et al., 2003). These geochemical data have been collected during two sampling cruises in the summer season (August 1996 and June 1999), both during the high-flow stage. The comparison between punctual measurements and calculated annual concentrations by B-WITCH involves additional uncertainties. The model calculates $\mathrm{Ca}^{2+}$ concentration ranging from $438 \mu \mathrm{mol} / \mathrm{L}$ to $1118 \mu \mathrm{mol} / \mathrm{L}$ (fig. 6a). These concentrations are in good agreement (same order of magnitude) with the measured values that varied between 613 
$\mu \mathrm{mol} / \mathrm{L}$ and $1178 \mu \mathrm{mol} / \mathrm{L}$ (Millot et al., 2003). Part of the discrepancy might reflect a difference in the integration time of weathering processes between the model and the river data. The model provides mean annual concentrations, while the concentrations reported in Millot et al. (2003) correspond to spot sampling measurements. The spatial variability in $\mathrm{Ca}^{2+}$ concentration closely reflects the lithology. The highest concentrations in $\mathrm{Ca}^{2+}$ are calculated for grid elements covered by carbonate rocks located in the northwest of the watershed and to the east of the Canadian Shield (Fig. 2). The lowest $\mathrm{Ca}^{2+}$ concentrations are calculated on granitic rocks (Canadian Shield and Rocky Mountains). $\mathrm{Mg}^{2+}$ concentrations are also correctly reproduced, with calculated values ranging between 161 and $367 \mu \mathrm{mol} / \mathrm{L}$ and measured values ranging between 220 and $673 \mu \mathrm{mol} / \mathrm{L}$ (fig. $6 \mathrm{~b}$ ). The $\mathrm{Mg}^{2+}$ concentration is mainly controlled by the dissolution of dolomite present in the deepest layer of the shale lithologies. $\mathrm{Na}^{+}$and $\mathrm{K}^{+}$are only supplied by slowly dissolving silicate minerals and their concentration is thus much lower than that of $\mathrm{Ca}$ and $\mathrm{Mg}$. Their concentration ranges between $11 \mu \mathrm{mol} / \mathrm{L}$ and $32 \mu \mathrm{mol} / \mathrm{L}$ for $\mathrm{K}^{+}$and between $82 \mu \mathrm{mol} / \mathrm{L}$ and $116 \mu \mathrm{mol} / \mathrm{L}$ for $\mathrm{Na}^{+}$. Calculated $\mathrm{K}^{+}$concentration is generally underestimated compared to field data, although still of the same order of magnitude (fig. 6c). $\mathrm{K}^{+}$is mainly provided by the dissolution of $\mathrm{K}$-feldspar and biotite minerals in granitic rocks and soils, and partly removed from solutions through illite precipitation. Over the six sub-basins, calculated $\mathrm{Na}^{+}$and $\mathrm{Cl}^{-}$concentrations are lower than measured concentrations but this difference can be explained by the dissolution of halite minerals (Hitchon et al., 1969; Millot et al., 2003). In the model, chlorine is only supplied by rainwater and $\mathrm{Na}^{+}$comes from both rainwater and the dissolution of plagioclase minerals. Accounting for halite dissolution would increase their concentration, however, modeling halite dissolution is beyond the capabilities of the WITCH model, which is designed to simulate highly diluted solutions. 


\subsubsection{Silica and main cation weathering fluxes :}

The net silica flux released by weathering reactions (dissolution-precipitation) for each subbasin is calculated and compared to the measurements performed by Millot et al. (2003). The silica weathering flux is set to zero for surface areas occupied by lakes. The calculated silica flux ranges from 0.29 to 2.44 tons $/ \mathrm{km}^{2} / \mathrm{yr}$, which is consistent with the measured flux, estimated between 0.73 and 1.69 tons $/ \mathrm{km}^{2} / \mathrm{yr}$. The calculated mean weathering flux over the whole watershed is 1.11 tons $/ \mathrm{km}^{2} / \mathrm{yr}$, very close to 1.24 tons $/ \mathrm{km}^{2} / \mathrm{yr}$ estimated by Millot et al. (2003). The silica flux released by weathering depends on the lithology and on the soil type, both prescribing the mineralogical composition of each individual weathering profile. The shale lithologies released more silica than the granitic crystalline area, with a mean flux of 1.8 tons $/ \mathrm{km}^{2} / \mathrm{yr}$ and to 0.05 tons $/ \mathrm{km}^{2} / \mathrm{yr}$ respectively.

The silica weathering flux is controlled in the model by secondary mineral reactivity in soils. Indeed, the dissolution of the Ca-montmorillonite mineral provides an exported silica flux of $667 \mathrm{~mol} \mathrm{Si} / \mathrm{ha} / \mathrm{yr}$, whereas the illite and kaolinite precipitation induces an uptake of silica of $91 \mathrm{~mol} \mathrm{Si} / \mathrm{ha} / \mathrm{yr}$ and $217 \mathrm{~mol} \mathrm{Si} / \mathrm{ha} / \mathrm{yr}$, respectively (table 1). The dissolution rate of primary minerals (andesine, anorthite, biotite, orthose, albite, and hornblende) is very low compared to that of the Ca-montmorillonite, culminating at about $5 \mathrm{~mol} \mathrm{Si} / \mathrm{ha} / \mathrm{yr}$.

The calcium and magnesium fluxes are mainly driven by the dissolution of calcite, dolomite, and Ca-montmorillonite minerals. The highest calcium fluxes are predicted for soils that contain both carbonate minerals and high concentrations of sulfates. When plotting the $\mathrm{Ca}^{2+}$ released by dolomite or calcite dissolution as function of the flux of $\mathrm{SO}_{4}{ }^{2-}$ released by pyrite oxidation, a direct linear relationship is observed for all of the subbasins (fig. $7 \mathrm{a}$ and $7 \mathrm{~b}$ ). Doubling the $\mathrm{SO}_{4}{ }^{2-}$ release results in a doubling of the carbonate dissolution. This simple result is obtained despite the addition of many non-linear processes impacting carbonate equilibrium (relationships between mineral dissolution and temperature or soil $\mathrm{CO}_{2}$ pressure, 
itself dependent on the biospheric productivity) and despite the large variability in lithology, climate or vegetal cover between the subbasins. Carbonate outcrops (excluding carbonaceous shales) are the second main contributor to the riverine $\mathrm{Ca}^{2+}$ production.

\subsubsection{Sensitivity to the saprolitic layer thickness :}

The thickness of the deep horizon (saprolitic layer) has been fixed at $0.5 \mathrm{~m}$ in the reference simulation. This rather thin value has been chosen to account for the permafrost which prevails under most of the watershed, freezing the bottom of the weathering profiles. Here we test the sensitivity of the model to the increase in the thickness of the deepest layer of the weathering profile. In some way, this test can be seen as a simple numerical test of the response of a boreal weathering system to the melting of the permafrost and to the deepening of the so-called active layer. All other parameters are assumed to be constant, and since the vegetation dynamic is only dependent on the hydrology of the two upper layers in LPJ, the vegetation cover remains unchanged.

The first order impact of a deepening of the bottom layer is the increase in the residence time of the water in contact with the bedrock, since the vertical drainage controlled by the vegetation cover and the climatic conditions remains unchanged in that simulation.

A doubling of the saprolitic layer thickness (from 0.5 to $1 \mathrm{~m}$ thickness) does not widely modify the release of chemical species from silicate minerals. The integrated silica flux released by silicate minerals only increases by $3 \%$ over the whole watershed. However, the calcium flux decreases by $8 \%$ and the magnesium flux rises by $32 \%$. While dolomite dissolution is enhanced, the $\mathrm{Ca}^{2+}$ released by calcite dissolution is limited by enhanced calcite precipitation. In the reference simulation $(0.5 \mathrm{~m}$ thick), calcite precipitation seldom occurs in some grid elements containing shale lithology in the Southern part of the Mackenzie watershed. This zone of calcite precipitation extends towards the center of the watershed 
when the thickness of the deep layer is increased. This process is promoted by the rise in $\mathrm{pH}$ which is itself driven by the increase in the water residence time.

\subsection{Impact of sulfuric acid on chemical weathering and $\mathrm{CO}_{2}$ budgets:}

Removing the production of sulfuric acid from pyrite oxidation has a deep impact on the weathering processes and fluxes occurring within the Mackenzie Basin. In this simulation (nopyr simulation), the mineralogical composition of soils and rocks as well as the climatic data remains unchanged. The purpose of this test is to quantify the role of sulfide oxidation on the atmospheric $\mathrm{CO}_{2}$ consumption by weathering processes in the watershed.

\subsubsection{Chemical weathering fluxes and cation fluxes to the river :}

The sodium and potassium concentrations remains almost unchanged between the two simulations (reference and nopyr simulations). For instance, the supply of $\mathrm{K}^{+}$to the river decreases by $5 \%$ at the very most, especially in the Bear sub-basin where sulfate production were particularly intense. Over the whole Mackenzie watershed, the supply of magnesium and calcium to the river decreases by $7 \%$ and $32 \%$, respectively, in the nopyr simulation compared to the reference run. The decrease in $\mathrm{Ca}^{2+}$ and $\mathrm{Mg}^{2+}$ may reach more than $60 \%$ and $20 \%$ respectively in the Bear watershed. The Peel and Liard sub-basins also display a large decrease in their $\mathrm{Ca}^{2+}$ and $\mathrm{Mg}^{2+}$ riverine concentration. These three sub-basins are particularly sensitive to the 'nopyr' test because they are mainly covered by carbonaceous shales and thus the production of sulfate by pyrite oxidation was high in the reference run. More precisely, the calcite dissolution decreases by $42 \%$ (from $649.8 \mathrm{~mol} / \mathrm{ha} / \mathrm{yr}$ to $374.1 \mathrm{~mol} / \mathrm{ha} / \mathrm{yr}$ ), and the dolomite dissolution decreases by $7 \%$ (from $268.5 \mathrm{~mol} / \mathrm{ha} / \mathrm{yr}$ to $248.5 \mathrm{~mol} / \mathrm{ha} / \mathrm{yr}$ ) in the nopyr simulation, compared to the reference simulation. 
Silicate mineral dissolution rate remains almost unchanged when the sulfuric acid production is removed (table 1). Silicate weathering does not appear to be sensitive to pyrite dissolution in the model, in the particular context of the Mackenzie Basin. This negligible impact of sulfide oxidation on silicate weathering may be related to the presence of carbonate minerals in all the weathering profiles where sulfide oxidation occurs. The dissolution of carbonate minerals quickly neutralizes the acidity produced by sulfide oxidation. Whether sulfate is accounted for or not, the soil solution on shale lithology reaches equilibrium with carbonate mineral according to their fast dissolution rate. The $\mathrm{pH}$ is slightly lower in the reference simulation (averaged decrease of 0.12 units over the area covered with shale lithology) but not enough to strongly impact silicate dissolution.

These results confirm that carbonate minerals are more sensitive than silicate minerals to the production of sulfuric acid by sulfide oxidation and that the chemical weathering budget of the watershed is controlled by the carbonate mineral reactivity.

\subsubsection{The $\mathrm{CO}_{2}$ consumption rate:}

Although it calculates the carbonate speciation depending on the alkalinity of the soil solutions and the below ground $\mathrm{pCO}_{2}$, the $\mathrm{B}-\mathrm{WITCH}$ model does not include explicitly a budget equation for carbon. The $\mathrm{CO}_{2}$ consumption rate by weathering reactions (in $\mathrm{mol} / \mathrm{km}^{2} / \mathrm{yr}$ ) is thus defined as the flux of bicarbonate ion originating from atmospheric $\mathrm{CO}_{2}$ at the outlet of the watershed that is produced through weathering reactions. It is thus equivalent to the difference between the total bicarbonate flux at the outlet and the sum of dissolved carbon fluxes originating from carbonate rocks (dolomite+calcite), $F_{\text {carb }}$ and from rainfall, $F_{\text {rain }}$. For each grid cell of each sub-basin the $\mathrm{CO}_{2}$ consumption rate $\left(\mathrm{C}_{\mathrm{CO} 2}\right)$ is calculated as follows:

$\mathrm{C}_{\mathrm{CO}_{2}}=\left[\mathrm{HCO}_{3}^{-}\right]_{\text {river }} \cdot W_{\text {river }}-F_{\text {carb }}-F_{\text {rain }}$ 
where $\left[\mathrm{HCO}_{3}^{-}\right]_{\text {river }} \cdot F_{\text {river }}=\left[\mathrm{HCO}_{3}^{-}\right]_{1} \cdot \mathrm{R}_{s}+\left[\mathrm{HCO}_{3}^{-}\right]_{3} \cdot \mathrm{D}_{r}$

and, $\left[\mathrm{HCO}_{3}^{-}\right]_{1},\left[\mathrm{HCO}_{3}^{-}\right]_{3}$ and $\left[\mathrm{HCO}_{3}{ }^{-}\right]_{\text {river }}$ correspond to the bicarbonate concentration in the surficial layer of the weathering profiles, in the saprolitic layer, and in the river, respectively. $W_{\text {river }}$ is the water flow leaving the grid cell and feeding the river. Frain is calculated as the product of the rainfall over the gridcell times the bicarbonate concentration in the rainwater. The riverine bicarbonate ion flux ranges from $9.710^{4} \mathrm{~mol} / \mathrm{km}^{2} / \mathrm{yr}$ to $33.610^{4} \mathrm{~mol} / \mathrm{km}^{2} / \mathrm{yr}$ in the reference simulation from one grid element to another, and between $11.010^{4} \mathrm{~mol} / \mathrm{km}^{2} / \mathrm{yr}$ and $38.010^{4} \mathrm{~mol} / \mathrm{km}^{2} / \mathrm{yr}$ in the nopyr simulation. The mean annual watershed bicarbonate ion flux (normalized to the modeled watershed surface area of 2.1 millions $\mathrm{km}^{2}$ ) is $17.910^{4}$ $\mathrm{mol} / \mathrm{km}^{2} / \mathrm{yr}$ in the reference simulation (total flux of $3.910^{11}$ moles of carbon $/ \mathrm{yr}$ ). The calculated effective $\mathrm{CO}_{2}$ consumption by weathering processes is $4.510^{4} \mathrm{~mol} / \mathrm{km}^{2} / \mathrm{yr}(0.94$ $10^{11} \mathrm{~mol} \mathrm{CO}_{2} / \mathrm{yr}$ ), representing $24 \%$ of the bicarbonate ion flux discharged to the ocean in the reference simulation, and $27 \%$ of the discharge of bicarbonate produced by weathering reactions. Overall, shield rocks consume $0.2410^{11}$ moles of atmospheric $\mathrm{CO}_{2} / \mathrm{yr}$, that is similar to the $\mathrm{CO}_{2}$ consumption through carbonate dissolution on the carbonate platform. The weathering of shale lithology consumes $0.4910^{11}$ moles of atmospheric $\mathrm{CO}_{2} / \mathrm{yr}$. The largest $\mathrm{CO}_{2}$ consumption rates are calculated where silica fluxes (fig. 8) and drainages (fig. 9) are the highest. Conversely, the lowest rates of $\mathrm{CO}_{2}$ consumption are associated with the highest carbonate dissolution rates promoted by sulfuric acid.

In the absence of cationic load in the rainfall, and if the lithology of the watershed was fully silicated and without sulfide mineral, $100 \%$ of the riverine $\mathrm{HCO}_{3}{ }^{-}$generated by weathering reactions would come from the atmosphere. On a long-term basis ( $10^{4}$ to $10^{6}$ years), the subsequent precipitation of carbonate minerals on the seafloor would release back to the atmosphere half of this carbon, leading to a maximum $\mathrm{CO}_{2}$ consumption of $50 \%$ of the riverine $\mathrm{HCO}_{3}{ }^{-}$. On the other hand, if the lithology was fully carbonated (without sulfide), 
only $50 \%$ of the riverine $\mathrm{HCO}_{3}{ }^{-}$generated by chemical weathering would come from the atmosphere. These $50 \%$ would then be released back to the atmosphere through carbonate precipitation on the seafloor; the net long term $\mathrm{CO}_{2}$ consumption of the watershed would be null. In the present simulation, we calculate that less than $50 \%$ of the riverine $\mathrm{HCO}_{3}{ }^{-}$ produced by weathering reactions $\left(27 \%\right.$, the rainfall $\mathrm{HCO}_{3}{ }^{-}$input being removed from the bicarbonate flux at the outlet) originates from the atmosphere. This estimate is lower than that proposed by Calmels et al. (2007) (27\% vs. $38 \%$ ), but in both case below the threshold of 50 $\%$. However, the proportion of dissolved inorganic carbon originating from carbonate rocks (ancient carbon) is roughly similar in both studies (65\% vs. $62 \%)$. These results mean that the Mackenzie watershed in its present state is a net source of carbon to the atmosphere, after considering the eventual carbonate precipitation in the oceanic realm. Indeed, the watershed releases $3.910^{11}$ moles/yr of bicarbonates to the ocean (rainfall input included). On the long term, half of this carbon will degas to the atmosphere $\left(2.010^{11} \mathrm{moles} / \mathrm{yr}\right)$ as a consequence of carbonate mineral precipitation on the seafloor. But the Mackenzie watershed consumes only $0.9410^{11}$ moles of atmospheric carbon through weathering processes. The difference between these two last numbers gives a potential release of about $1.110^{11}$ moles $\mathrm{CO}_{2} / \mathrm{yr}$ to the atmosphere at the geological timescale. Once the rainfall input of $0.510^{11}$ moles $\mathrm{HCO}_{3}^{-} / \mathrm{yr}$ removed from this outgassing flux, we found that the weathering processes in the Mackenzie watershed release of $0.610^{11}$ moles $\mathrm{CO}_{2} / \mathrm{yr}$ to the atmosphere. This conclusion holds for timescales above the mixing time of the ocean $\left(10^{4}\right.$ years $)$, but below the residence time of the sulfur in seawater $\left(10^{7}\right.$ years $)$, a timescale above which the cycle of sulfide oxidation on land and sulfate reduction in oceanic sediments can be considered at steady state.

At the annual timescale, the Peel and Bear sub-basins display negative rates of $\mathrm{CO}_{2}$ consumption (fig. 10). A negative flux means that the input of $\mathrm{HCO}_{3}{ }^{-}$through rain at the top of the weathering profile exceeds the output flux of atmospheric $\mathrm{CO}_{2}$ (from rain and 
weathering reactions) through surficial runoff and deep drainage. This occurs on carbonaceous shale lithologies where the sulfate release is particularly high (calibrated release flux from pyrite weathering ranging from 0.05 to $0.5 \mathrm{moles} / \mathrm{m}^{2} / \mathrm{yr}$ of $\mathrm{SO}_{4}{ }^{2-}$ ) and might reflects an overestimation of the rain input, as discussed in the previous paragraph. However, those negative $\mathrm{CO}_{2}$ consumption fluxes might also be explained by high sulfate release that strongly decreases the alkalinity of the soil solutions, eventually leading to a net $\mathrm{CO}_{2}$ degassing. A restricted part of the Mackenzie basin would thus be a net $\mathrm{CO}_{2}$ source at the yearly timescale, despite intense weathering.

The negative $\mathrm{CO}_{2}$ consumption areas disappear when the pyrite-derived sulfate source is removed from the model. The nopyr simulation shows a moderate increase in the riverine bicarbonate flux (from $17.910^{4} \mathrm{~mol} / \mathrm{km}^{2} / \mathrm{yr}$ in the reference simulation to $20.410^{4}$ $\mathrm{mol} / \mathrm{km}^{2} / \mathrm{yr}$ in the nopyr simulation), but the $\mathrm{CO}_{2}$ consumption by weathering reactions increases by a factor of 2.3 , with a mean annual value of $10.310^{4} \mathrm{~mol} / \mathrm{km}^{2} / \mathrm{yr}$. In the nopyr simulation, $56 \%$ of the calculated dissolved inorganic carbon released to the river through weathering reactions (i.e. $56 \%$ of the total bicarbonate flux at the outlet minus the bicarbonate input through rainfall) originate from the atmosphere. Those results suggest that the release of acidity through sulfide oxidation, i.e., the presence of sulfide minerals within a river basin, strongly reduces the atmospheric $\mathrm{CO}_{2}$ consumption by weathering processes. However, a lower $\mathrm{CO}_{2}$ consumption rate does not mean that the chemical weathering rate is lower; in fact, chemical weathering rates are higher in the reference run than in the nopyr simulation. As the source of carbonic acid (atmospheric/soil $\mathrm{CO}_{2}$ ) remains the same in the two simulations, our study shows that the differing sources of acidity in the weathering zone cannot be summed.

\section{Conclusions and perspectives :}


The B-WITCH model, coupling a dynamic global biospheric model with a process-based model describing continental weathering, is able to reproduce the main cation export by the Mackenzie River. The release of sulfate anions and protons by pyrite oxidation has been implemented as a forcing function of the model, using field data to calibrate the sulfate flux into the weathering profiles. Calcium, magnesium and potassium export are well reproduced. The mean sodium and chlorine concentrations are underestimated over the watershed, suggesting a contribution from halite dissolution that is not modeled here. The mean annual silica flux released by weathering over the whole catchment is in close agreement with the field-based estimate of Millot et al. (2003). The salient results are that:

(1) the dissolved silica export is controlled by secondary mineral solubility in soils;

(2) the calcium and magnesium fluxes are primarily driven by the dissolution of calcite, and dolomite, and alternatively by Ca-smectite dissolution. The most important contribution comes from area covered by carbonaceous shales, where high sulfide oxidation rate is prescribed;

(3) The atmospheric $\mathrm{CO}_{2}$ consumption by the Mackenzie river is equal to $27 \%$ of the bicarbonate flux produced by weathering reactions and released to the ocean, that is of the same order than the previous estimate based on field data $(38 \%$, Calmels et al., 2007). This result confirms that the Mackenzie watershed is a source of carbon at geological timescale (potential release of $0.610^{11}$ moles $\mathrm{CO}_{2} / \mathrm{yr}$ to the atmosphere);

(4) The production of sulfuric acid trough sulfide oxidation, hence, the presence of sulfide minerals within a river basin, reduces the net consumption of atmospheric $\mathrm{CO}_{2}$ by chemical weathering of rocks. We show that the net consumption of atmospheric $\mathrm{CO}_{2}$ for the Mackenzie River Basin would be twice the actual value if the lithology of the watershed was lacking of sulfide minerals. 
The Mackenzie River basin is one of the most important arctic watershed in terms of water and chemicals discharged to the ocean. As previously noted and emphasized in this work, accounting for weathering reactions not promoted by carbonic acid is of primary importance in the reconstruction of the watershed carbon budget. Here, sulfate production by pyrite oxidation has been prescribed from field data, but pyrite oxidation seems directly dependent on the mechanical erosion of the shale lithologies (Calmels et al., 2007). Erosion brings pyrite in contact with the atmospheric $\mathrm{O}_{2}$ and promotes sulfuric acid production. This further stresses the need for a coupled modeling approach for chemical weathering and physical erosion.

\section{Acknowledgments}

This work has been funded by the EC2CO/INSU-CNRS project « Les processus d'altération continentale à grande échelle: Modélisation appliquée au cas du bassin de la Mac Kenzie ». Didier Gazen (Laboratoire d'Aérologie, Toulouse) is greatly acknowledged for the maintenance of the cluster of PC at the OMP, and Bertrand Guerrero (GET, Toulouse) is acknowledged for the establishment of the databases. E.B. thank the participants to the 2010 sampling campaign on the Mackenzie basin for fruitful discussions. Bernhard PeuckerEhrenbrink is acknowledged for helpful discussions. Two anonymous reviewers and the associated editor Joel D. Blum are greatly acknowledged for their careful and constructive reviews, that contribute to improve the original manuscript. 


\section{References}

Alkattan, M., Oelkers, E.H., Dandurand, J.L., Schott, J., 1998. An experimental study of calcite and limestone dissolution rates as a function of $\mathrm{pH}$ from -1 to 3 and temperature from 25 to 80 degrees C. Chem. Geol. 151, 199-214.

Amiotte-Suchet, P., Probst, J.-L., Ludwig, W., 2003. Worldwide distribution of continental rock lithology: Implications for atmospheric/soil $\mathrm{CO}_{2}$ uptake by continental weathering and alkalinity river transport to the oceans. Global Biogeochem. Cycle 17, doi :10.1029/2002GB001891.

Anderson, S.P., Drever, J.I., Frost, C.D., Holden, P., 2000. Chemical weathering in the foreland of a retreating glacier. Geochim. Cosmochim. Acta. 64, 1173-1189.

Arnorsson, S., Stefansson, A., 1999. Assessment of feldspar solubility in water in the range $0-350^{\circ} \mathrm{C}$ at $\mathrm{P}_{\text {sat. }}$ Am. J. Sci. 299, 173-209.

Arocena, J. M., Sanborn, P., 1999. Mineralogy and genesis of selected soils and their implications for forest management in central and northeastern British Columbia. Can. J. Soil Sci. 79, 571-592.

Batjes, N.H., 2005. ISRIC-WISE global data set of derived soil properties on a 0.5 by 0.5 Degree grid (Version 3.0). Report 2005/02, ISRIC-World Information.

Beaulieu, E., Goddéris, Y., Labat, D., Roelandt, C. Oliva, P., Guerrero, B., 2010. Impact of atmospheric $\mathrm{CO}_{2}$ levels on continental silicate weathering. Geochem. Geophys. Geosyst. 11, 1-18.

Berner, R.A., Lasaga, A.C., Garrels, R.M., 1983. The carbonate-silicate geochemical cycle an dits effect on atmospheric carbon dioxide over the past 100 million years. Am. J. Sci. 284,1183-1192.

Berner, R.A., Kothavala, Z., 2001. GEOCARB III : A revised model of atmospheric $\mathrm{CO}_{2}$ over Phanerozoic time. Am. J. Sci. 301, 182-204. 
Bertram, H.L., Das, N.C., Lau, Y.K., 1986. Precipitation Chemistry Measurement in Alberta. Water Air Soil Pollut. 30, 231-237.

Best, M. G., 2003. Igneous and Metamorphic Petrology. 752 pp., Blackwell Sci., Malden, Mass.

Blum, A.E., Stillings, L.L., 1995. Feldspar dissolution kinetics, In Chemical Weathering Rates of Silicate Minerals. Mineralo. Soc. Am., Washington.

Calmels, D., Gaillardet, J., Brenot, A., France-Lanord, C., 2007. Sustained sulfide oxidation by physical erosion processes in the Mackenzie River basin: Climatic persperctives. Geology 35, 1003-1006.

Castet, S., Dandurand, J.-L., Schott, J., Gout, R., 1993. Boehmite solubility and aqueous aluminium speciation in hydrothermal solutions $\left(90-350^{\circ} \mathrm{C}\right)$ : Experimental study and modeling. Geochim.Cosmochim. Acta 57, 4869-4884.

Chaïrat, C., 2005. Etude expérimentale de la cinétique et des mécanismes d'altération de minéraux apatitiques: Application au comportement d'une céramique de confinement d'actinides mineurs. PhD thesis, Université Paul Sabatier, Toulouse.

de Caritat, P., Bloch, J. D., Hutcheon, I. E., Longstaffe, F. J., 1994. Compositional trends of a cretaceous foreland basin shale (Belle Fourche formation, Western Canada sedimentary basin): Diagenetic and depositional controls. Clay Miner. 29, 503-526.

Delgado, R., Martin-Garcia, J. M., Oyonarte, C., Delgado, G., 2003. Genesis of the terrae rossae of the Sierra Gador. Eur. J. Soil Sci. 54, 1-16.

Dessert, C., Dupré, B., François, L.M., Schott, J., Gaillardet, J., Chakrapani, G.J., Bajpai, S., 2001. Erosion of Deccan Traps determined by river geochemistry : impact on the global climate and the $87 \mathrm{Sr} / 86 \mathrm{Sr}$ ratio of seawater. Earth Planet. Sci. Lett. 188 (3/4), 459-474.

Devidal, J.L., Schott, J., Dandurand, J.-L., 1997. An experimental study of kaolinite dissolution and precipitation kinetics as a function of chemical affinity and solution 
composition at $150^{\circ} \mathrm{C}, 40$ bars, and $\mathrm{pH} 2,6.8$ and 7.8. Geochim. Cosmochim. Acta 61, 51655186.

Dove, P.M., 1994. The Dissolution Kinetics of Quartz in Sodium-Chloride Solutions at 25- Degrees-C to 300-Degrees-C. Am. J. Sci. 294, 665-712.

Drever, J.I., 1997. The Geochemistry of Natural Waters. Prentice Hall, Upper Saddle River, New Jersey 07458.

Dewis, F.J., Levinson, A.A., Bayliss, P., 1972. Hydrogeochemistry of the surface waters of the Mackenzie River drainage basin, Canada-IV. Boron-salinity-clay mineralogy relationships in modern deltas. Geochim. Cosmochim. Acta. 36, 1359-1375.

Donnadieu, Y., Pierrehumbert, R., Jacob, R., Fluteau, F., 2006. Modelling the primary control of paleogeography on Cretaceous climate. Earth Planet. Sci. Lett. 248, 426-437.

Eyring, H., 1935. The activated complex in chemical reactions. J. Chem. Phys. 3, 107115.

FAO/IIASA/ISRIC/ISS_CAS/JRC, 2008. Harmonized World Soil Database (version 1.0). FAO, Rome, Italy and IIASA, Laxenburg, Austria.

Gaillardet, J., Dupré, B., Louvat, P., Allègre, C.J., 1999. Global silicate weathering and $\mathrm{CO}_{2}$ consumption rates deduced from the chemistry of large rivers. Chem. Geol. 159, 330.

Gaillardet, J., Millot, R., Dupré, B., 2003. Chemical denudation rates of the western Canadian orogenic belt : The Stikine terrane. Chem. Geol. 201, 257-259.

Galy, A., France-Lanord, C., 1999. Weathering processes in the Ganges-Brahmaputra basin and the riverine alkalinity budget, Chem. Geol. 159, 31-60

Gislason, S.R., Oelkers, E.H., Eiriksdottir, E.S., Kardjilov, M.I., Gisladottir, G., Sigfusson, B., Snorrason, A., Elefsen, S., Hardardottir, J., Torssander, P., Oskarsson, N., 2009. Direct evidence of the feedback between climate and weathering. Earth Planet. Sci. 
Lett. 277, 213-222.

Goddéris, Y., François, L.M., 1995. The Cenozoic evolution of the strontium and carbon cycles : relative importance of continental erosion and mantle exchanges. Chem. Geol. $126,169-190$.

Goddéris, Y., Donnadieu, Y., Nédélec, A., Dupré, B., Dessert, C., François, L.M., Grard, A., Ramstein, G., 2003. The Sturtian glaciation: fire and ice. Earth Planet. Sci. Lett. $211,1-12$.

Goddéris, Y., François, L.M., Probst, A., Schott, J., Moncoulon, D., Labat, D., Viville, D., 2006. Modelling weathering processes at the catchment scale: The WITCH numerical model. Geochim. Cosmochim. Acta. 70, 1128-1147.

Goddéris, Y., Roelandt, C., Schott, J., Pierret, M.-C., François, L. M., 2009. Towards an integrated model of weathering, climate, and biospheric processes. Rev. Mineral. Geochem. 70, 411-434.

Goddéris, Y., Williams, J. Z., Schott, J., Pollard, D., Brantley, S. L., 2010. Time evolution of the mineralogical composition of Mississippi Valley loess over the last $10 \mathrm{kyr}$ : Climate and geochemical modeling. Geochem. Cosmochem. Acta 74, 6357-6374.

Guidry, M.W., Mackenzie, F.T., 2003. Experimental study of igneous and sedimentary apatite dissolution : control of $\mathrm{pH}$, distance from equilibrium, and temperature on dissolution rates. Geochim. Cosmochim. Acta 67, 2949-2963.

Hercod, D.J., Brady, P.V., Gregory, R.T., 1998. Catchment-scale coupling between pyrite oxidation and calcite weathering. Chem. Geol. 151, 259-276.

Hidy, G.M., 2003. Snowpack and precipitation chemistry at high altitudes. Atmos. Environ. 37, 1231-1242. 
Hitchon, B., Levinson, A.A., Reeder, S.W., 1969. Regional Variations of River Water Composition Esulting from Halite Solution, Mackenzie River Drainage Basin, Canada. Water Resour. Res. 5, 1395-1403.

Holmqvist, J., 2001. Modelling chemical weathering in different scales. PhD thesis, Lund University, Lund.

Kohut, C., Muehlenbachs, K., Dudas, M.J., 1995. Authigenic Dolomite in a Saline Soil in Alberta, Canada. Soil Sci. Soc. Am. J. 59, 1499-1504.

Köhler, S.J., Dufaud, F., Oelkers, E.H., 2003. An experimental study of illite dissolution kinetics as a function of $\mathrm{pH}$ from 1.4 to 12.4 and temperature from 5 to $50^{\circ} \mathrm{C}$. Geochim. Cosmochim. Acta 67, 3583-3594.

Lerman, A., Wu, L., Mackenzie, F.T., 2007. $\mathrm{CO}_{2}$ and $\mathrm{H}_{2} \mathrm{SO}_{4}$ consumption in weathering and material transport to the ocean, and their role in the global carbon balance, Mar. Chem. 106, 326-350

Li, S.-L., Calmels, D., Han, G., Gaillardet, J., Liu, C.Q., 2008. Sulfuric acid as an agent of carbonate weathering constrained by $\mathrm{d}^{13} \mathrm{C}_{\mathrm{DIC}}$ : Examples from Southwest China, Earth Planet. Sci. Lett. 270, 189-199.

Louie, P.Y.T., Hogg, W.D., MacKay, M.D., Zhang, X., Hopkinson, R.F., 2002. The Water Balance Climatology of the Mackenzie Basin with Reference to the 1994/95 Water Year. Atmos. Ocean. 40(2), 159-180.

Maher, K., Steefel, C.I., White, A., Stone, D.A., 2009. Chemical weathering of a marine terrace chronosequence, Santa Cruz, California III : the role of secondary minerals and hydrology in regulating weathering rates through reaction affinity. Geochim. Cosmochim. Acta. 73, 2769-2803.

Michel, F.A., 1986. Hydrogeology of the central Mackenzie Valley. J. Hydrol. 85, $379-405$. 
Millot, R., Gaillardet,, J., Dupré, B., Allègre, C.J., 2003. Northern latitude chemical weathering rates: Clues from the Mackenzie River Basin, Canada. Geochim. Cosmochim. Acta. 67(7), 1305-1329.

Mitchell, T.D., Jones, P.D., 2005. An improved method of constructing a database of monthly climate observations and associated high-resolution grids. Int. J. Climatol. 25, 693712.

Moulton, K.L., West, J., Berner, R.A., 2000. Solute flux and mineral mass balance approaches to the quantification of plant effects on silicate weathering. Am. J. Sci. 300, 539570.

Nagy, K.L., 1995. Dissolution and precipitation kinetics of sheet silicates, In Chemical Weathering Rates of Silicate Minerals. Mineral. Soc. Am., Washington.

Natural Ressources Canada, 1993. Vegetation Cover (map), 5th edition, National Atlas of Canada.

Natural Ressources Canada, 1995. Canada-Permafrost (map), 5th edition, National Atlas of Canada.

Navarre-Sitchler, A., Brantley, S., 2007. Basalt weathering across scales. Earth Planet. Sci. Lett. 261, 321-334.

New, M., Hulme, M., Jones, P.D., 2000. Representing twenthieth century space-time climate variability, Part 2: development of 1901-96 monthly grids of terrestrial surface climate. J. Clim. 13, 2217-2238.

Oliva, P., Viers, J., Dupré, B., 2003. Chemical weathering in granitic environments. Chem. Geol. 202, 225-256.

Oelkers, E.H., Schott, J., Devidal, J.L., 1994. The effect of aluminium, pH and chemical affinity on the rates of aluminosilicate dissolution reactions. Geochim. Cosmochim. Acta 58, 2011-2024. 
Pokrovsky, O.S., Golubev, S.V., Jordan, G., 2009. Effect of organic and inorganic ligands on calcite and magnesite dissolution rates at 60 degrees $\mathrm{C}$ and 30 atm $\mathrm{pCO}_{2}$. Chem. Geol. 265, 33-43.

Pokrovsky, O.S., Schott, J., 1999. Porcesses at the magnesium-bearing-bearing carbonates/solution interface. II. Kinetics and mechanism of magnesite dissolution. Geochim. Cosmochim. Acta 63, 881-897.

Pokrovsky, O.S., Schott, J., 2000. Kinetics and mechanism of forsterite dissolution at $25^{\circ} \mathrm{C}$ and $\mathrm{pH}$ from 1 to 12 . Geochim. Cosmochim. Acta 64, 3313-3325.

Pokrovsky, O.S., Schott, J., Thomas, F., 1999. Dolomite surface speciation and reactivity in aquatic systems. Geochim. Cosmochim. Acta 63, 3133-3143.

Prowse, T.D., Conly, F.M., Church, M., English, M.C., 2002. A review of hydrological results of the Northern River Basins study, Canada, Part 1. Peace and Slave Rivers. River Res. Appl. 18, 429-446.

Reeder, S.W., Hitchon, B., Levinson, A.A., 1972. Hydrogeochemistry of the surface waters of the Mackenzie River drainage basin, Canada-I. Factors controlling inorganic composition. Geochim. Cosmochim. Acta. 36, 825-865.

Roelandt, C., Goddéris, Y., Bonnet, M.-P., Sondag, F., 2010. Coupled modelling of biospheric and chemical weathering processes at the continental scale. Global Biogeochem. Cycles. 24, doi:10.1029/2008GB003420.

Rostad, H.P.W., 1975. Diagenesis of Postglacial Carbonate Deposits in Saskatchewan. Can. J. Earth Sci. 12, 798-806.

Rouse, W.R., 2000. Progress in hydrological research in the Mackenzie GEWEX study. Hydrol. Processes. 14, 1667-1685.

Rühlmann, J., Körschens, M., Graefe, J., 2006. A new approach to calculate the particle density of soils considering properties of the soil organic matter and the mineral matrix. 
Geoderma 130, 272-283.

Salminen, R., Gregorauskiene, V., Tarvainen, T., 2008. The normative mineralogy of 10 soil profiles in Fennoscandia and north-western Russia. Appl. Geochem. 23, 3651-3665.

Schott, J., Oelkers, E.H., 1995. Experimental study of anorthite dissolution and the relative mechanism of feldspar hydrolysis. Geochim. Cosmochim. Acta 59, 5039-5053.

Shaw, D.B., Weaver, C.E., 1965. The mineralogical composition of shales. J. Sediment. Petrol. 35, 213-222.

Spence, J., Telmer, K., 2005. The role of sulfur in chemical weathering and atmospheric $\mathrm{CO}_{2}$ fluxes : Evidence from major ions, $\delta^{13} \mathrm{C}_{\mathrm{DIC}}$, and $\delta^{34} \mathrm{~S}_{\mathrm{SO} 4}$ in rivers of the Canadian Cordillera. Geochim. Cosmochim. Acta. 69(23), 5441-5458.

Stewart, R.E., Leighton, H.G., Marsh, P., Moore, G.W.K., Ritchie, H., Rouse, W.R., Soulis, E.D., Strong, G.S., Crawford, R.W., Kochtubajda, B., 1998. The Mackenzie GEWEX Study: The Water and Energy Cycles of a Major North American River Basin. Am. Meteorolog. Soc. 79, 2665-2683.

Sverdrup, H., Warfinge, P., 1995. Estimating field weathering rates using laboratory kinetics, In Chemical Weathering Rates of Silicate Minerals. Mineral. Soc. Am., Washington.

Van Der Linden, S., Woo, M., 2003. Transferability of hydrological model parameters between basins in data-sparse areas, subarctic Canada. J. Hydrol. 270, 182-194.

Vieillard, P., 2000. A new method for the prediction of Gibbs free energies of formation of hydrated clay minerals based on the electronegativity scale. Clays Clay Miner. $48,459-473$.

Violette, A., Goddéris, Y., Maréchal, J.-C., Riotte, J., Oliva, P., Mohan Kumar, M.S., Sekhar, M. Braun, J.-J., 2010. Modelling the chemical weathering fluxes at the watershed scale in the Tropics (Mule Hole, South India) : Relative contribution of the smectite/kaolinite assemblage versus primary minerals. Chem. Geol. 277, 42-60. 
Walker, J.C., Hays, P.B., Kasting, J.F., 1981. A negative feedback mechanism for the long-term stabilization of Earth's surface temperature. J. Geophys. Res. 86 (C10), 9776-9782.

Wallmann, K., 2001. Controls on the Cretaceous and Cenozoic evolution of seawater composition, atmospheric $\mathrm{CO}_{2}$ and climate. Geochim. Cosmochim. Acta. 65, 3005-3025.

Walther, J.V., Heldeson, H.C., 1977. Calculation of Thermodynamic Properties of Aqueous Silica and Solubility of Quartz and Its Polymorphs at High-Pressures and Temperatures. Am. J. Sci. 277, 1315-1351.

Wesolowski, D.J., Palmer, D.A., 1994. Aluminium speciation and equilibria in aqueous solution : V. Gibbsite solubility at $50^{\circ} \mathrm{C}$ and $\mathrm{pH}$ 3-9 in 0.1 molal $\mathrm{NaCl}$ solutions (a general model for aluminium speciation; analytical methods). Geochim. Cosmochim. Acta $58,2947-2969$.

West, A.J., Galy, A., Bickle, M., 2005. Tectonic and climatic controls on silicate weathering. Earth Planet. Sci. Lett. 235, 211-228.

White, A.F., Blum, A.E., 1995. Effects of climate on chemical weathering in watersheds. Geochim. Cosmochim. Acta. 59, 1729-1747.

Wiseman, C. L. S., Püttmann, W., 2006. Interactions between mineral phases in the preservation of soil organic matter. Geoderma 134, 109-118.

Wollast, R., 1990. Rate and mechanism of dissolution of carbonates in the system $\mathrm{CaCO}_{3}-\mathrm{MgCO}_{3}$. In : Stumm, W. (Ed), Aquatic Chemical Kinetics. John Wiley, New York.

Woo, M.-K., Thorne, R., 2003. Streamflow in the Mackenzie Basin, Canada. Arctic. 56(4), 328-340.

Yi, Y., Brock, B.E., Falcone ,M.D., Wolfe, B.B., Edwards, T.W.D., 2008. A coupled isotope tracer method to characterize input water to lakes. J. Hydrol. 350, 1-13. 


\section{Figure captions}

Figure 1: The geographical zones (Cordillera, Interior Platform and Canadian Shield) and the major sub-basins (Peel, Bear, Liard, Slave, Peace and Athabasca) of the Mackenzie catchment (modified from Millot et al., 2003).

Figure 2 : Lithological map of the Mackenzie watershed from Amiotte-Suchet et al. (2003). Three lithological types are recognized in the Mackenzie watershed: shield rocks (brown), shales (green) and carbonates (pink).

Figure 3: B-WITCH model represention of the water fluxes and the sulfate ions concentrations for each grid element. $\left[\mathrm{SO}_{4}{ }^{2-}\right]_{1}$ and $\left[\mathrm{SO}_{4}{ }^{2-}\right]_{3}$ represent the surficial and deep $\mathrm{SO}_{4}{ }^{2-}$ concentrations $(\mathrm{mol} / \mathrm{L})$ respectively, $\left[\mathrm{SO}_{4}{ }^{2-}\right]_{\text {river }}$ is the $\mathrm{SO}_{4}{ }^{2-}$ concentration into the river $(\mathrm{mol} / \mathrm{L}), \mathrm{R}_{1}$ is the surficial runoff $(\mathrm{mm} / \mathrm{yr}), \mathrm{D}_{3}$ is the deep drainage $(\mathrm{mm} / \mathrm{yr})$, and $\mathrm{S}$ is the river water flow (sum of deep drainage and surficial runoff).

Figure 4 : Spatial representation of River sulfate ions flux $\left(\mathrm{mol} / \mathrm{m}^{2} / \mathrm{yr}\right)$ from pyrite dissolution calculated by B-WITCH.

Figure 5: Spatial representation of River water flow $(\mathrm{mm} / \mathrm{yr})$, representing the sum of surficial runoff and deep drainage calculated by LPJ for all grid elments of watershed.

Figure 6: (a) Mean calcium concentration ( $\mu \mathrm{mol} / \mathrm{L})$, (b) mean magnesium concentration $(\mu \mathrm{mol} / \mathrm{L})$, and (c) mean potassium concentration $(\mu \mathrm{mol} / \mathrm{L})$, for the Peel, Bear, Liard, Slave, Peace and Athabasca sub-basin (black: measured values by Millot et al. (2003), gray: calculated values by B-WITCH).

Figure 7: Calcium flux $\left(10^{-2} \mathrm{~mol} / \mathrm{m}^{2} / \mathrm{yr}\right)$ from calcite dissolution (a) and from dolomite dissolution (b) versus $\mathrm{SO}_{4}{ }^{2-}$ flux $\left(10^{-2} \mathrm{~mol} / \mathrm{m}^{2} / \mathrm{yr}\right)$ from pyrite dissolution, calculated by BWITCH on each grid element of sub-basins (black: Peel basin; red: Bear basin; yellow: Liard basin; green: Slave basin; violet: Peace basin; orange: Athabasca basin). 
Figure 8: $\mathrm{CO}_{2}$ consumption flux $\left(10^{-1} \mathrm{~mol} / \mathrm{m}^{2} / \mathrm{yr}\right)$ versus $\mathrm{H}_{4} \mathrm{SiO}_{4}$ flux $\left(10^{-2} \mathrm{~mol} / \mathrm{m}^{2} / \mathrm{yr}\right)$ calculated by B-WITCH for each grid element of sub-basins (blue : only grid cells located on carbonate lithology; red and green : only grid cells located on Peel and Bear sub-basins respectively; black: only grid cells located on Liard, Slave, Peace and Athabasca subbasins).

Figure 9: $\mathrm{H}_{4} \mathrm{SiO}_{4}$ flux $\left(\mathrm{t} / \mathrm{km}^{2} / \mathrm{yr}\right)$ calculated by $\mathrm{B}-\mathrm{WITCH}$ versus deep drainage $(\mathrm{mm} / \mathrm{yr})$ calculated by LPJ model, only for grid cells located on granitic and shales lithologies.

Figure 10 : Spatial representation of the $\mathrm{CO}_{2}$ consumption flux $\left(\mathrm{mol} / \mathrm{m}^{2} / \mathrm{yr}\right)$ calculated by BWITCH on Mackenzie basin.

Table 1 : Silica, Calcium and Magnesium flux (averaged over whole watershed, $\mathrm{mol} / \mathrm{ha} / \mathrm{yr}$ ), obtained by reference simulation and by simulation without pyrite dissolution (nopyr simulation). 
reference simulation nopyr simulation

\begin{tabular}{l|c|c|c|c|c|c}
\hline Averaged flux (mol/ha/yr) & $\mathbf{S i}$ & $\mathbf{C a}$ & $\mathbf{M g}$ & $\mathbf{S i}$ & $\mathbf{C a}$ & $\mathbf{M g}$ \\
\hline Silicates mine rals & & & & & & \\
Anorthite & 0.61 & 0.30 & & 0.61 & 0.30 & \\
Albite & 0.63 & & & 0.63 & & \\
Orthose & 0.22 & & & 0.22 & & \\
Biotite & 0.12 & & 0.06 & 0.12 & & 0.06 \\
Andesine & 2.28 & 0.25 & & 2.28 & 0.25 & \\
Chlorite & 0.21 & & 0.35 & 0.21 & & 0.35 \\
Ca-montmorillonite & 666.6 & 27.50 & 54.99 & 666.2 & 27.48 & 54.96 \\
Mg-montmorillonite & 6.63 & & 0.83 & 6.61 & & 0.83 \\
Illite & -90.77 & -0.26 & -11.25 & -90.76 & -0.26 & -11.25 \\
Hornblend & 0.20 & 0.06 & 0.11 & 0.20 & 0.06 & 0.11 \\
Apatite & & 11.16 & & & 11.16 & \\
Kaolinite & -217.28 & & & -217.07 & & \\
\hline Carbonates minerals & & 918.2 & 268.5 & & 622.6 & 248.5 \\
\hline Total & 369.4 & 957.2 & 313.6 & 369.2 & 661.5 & 293.5 \\
\hline
\end{tabular}

Table 1 


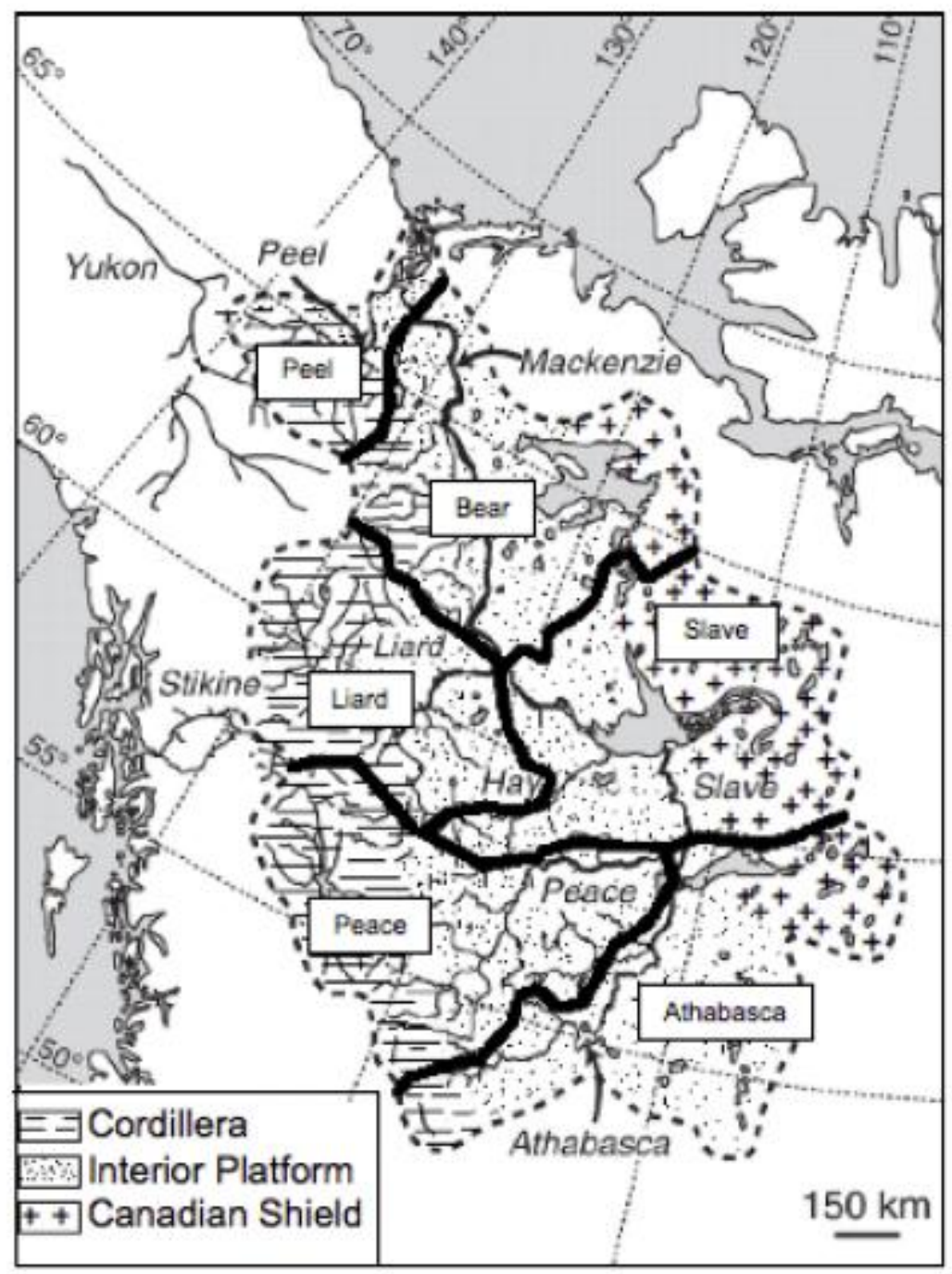

Figure 1 


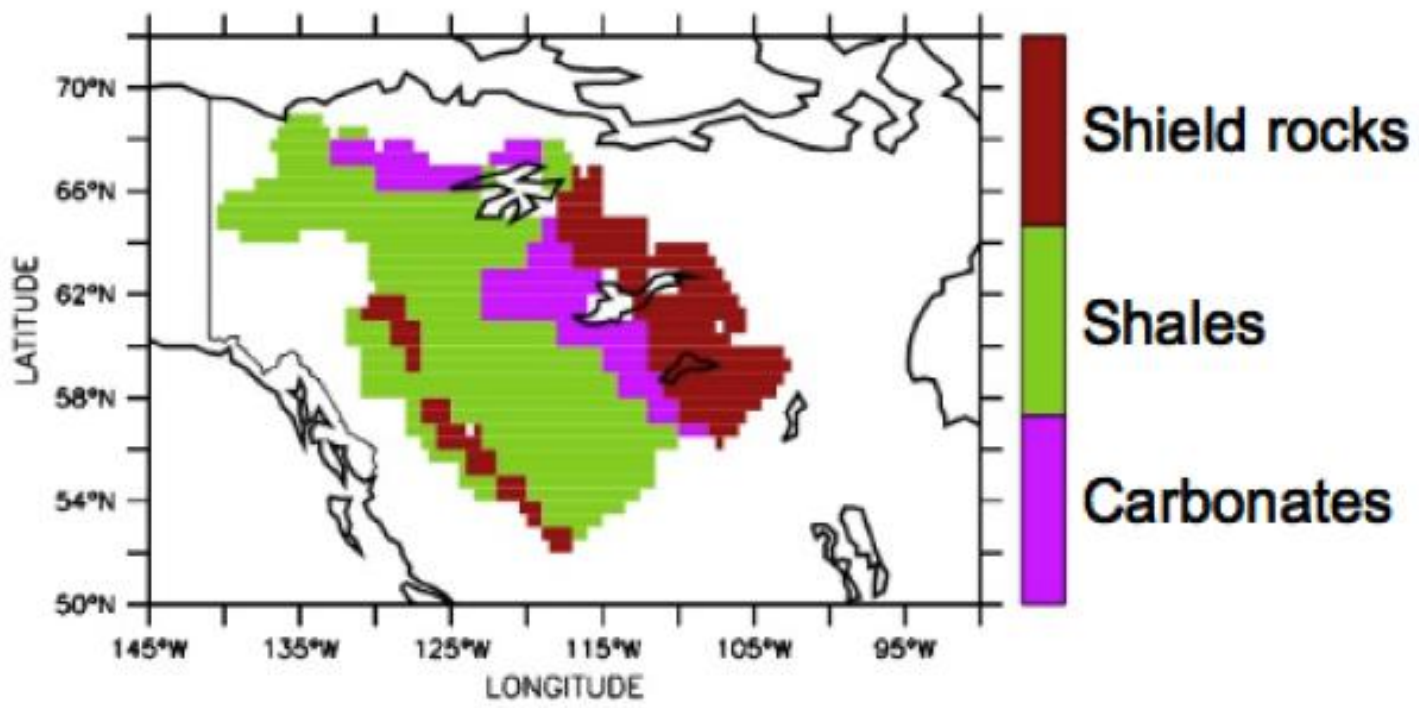

Figure 2 


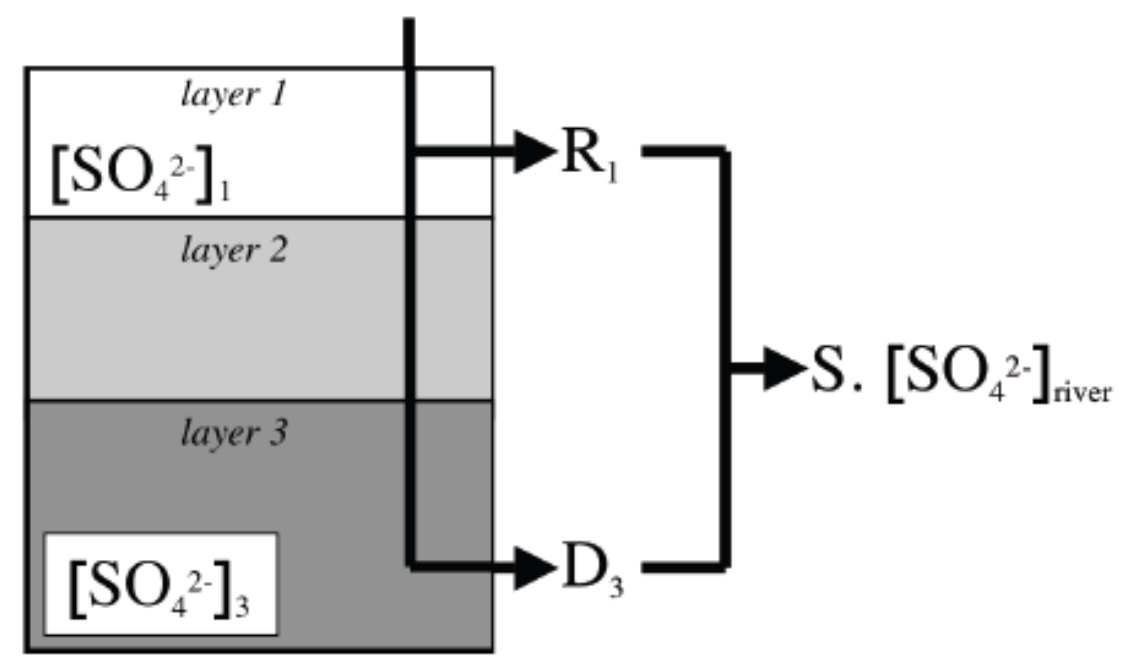

Figure 3 


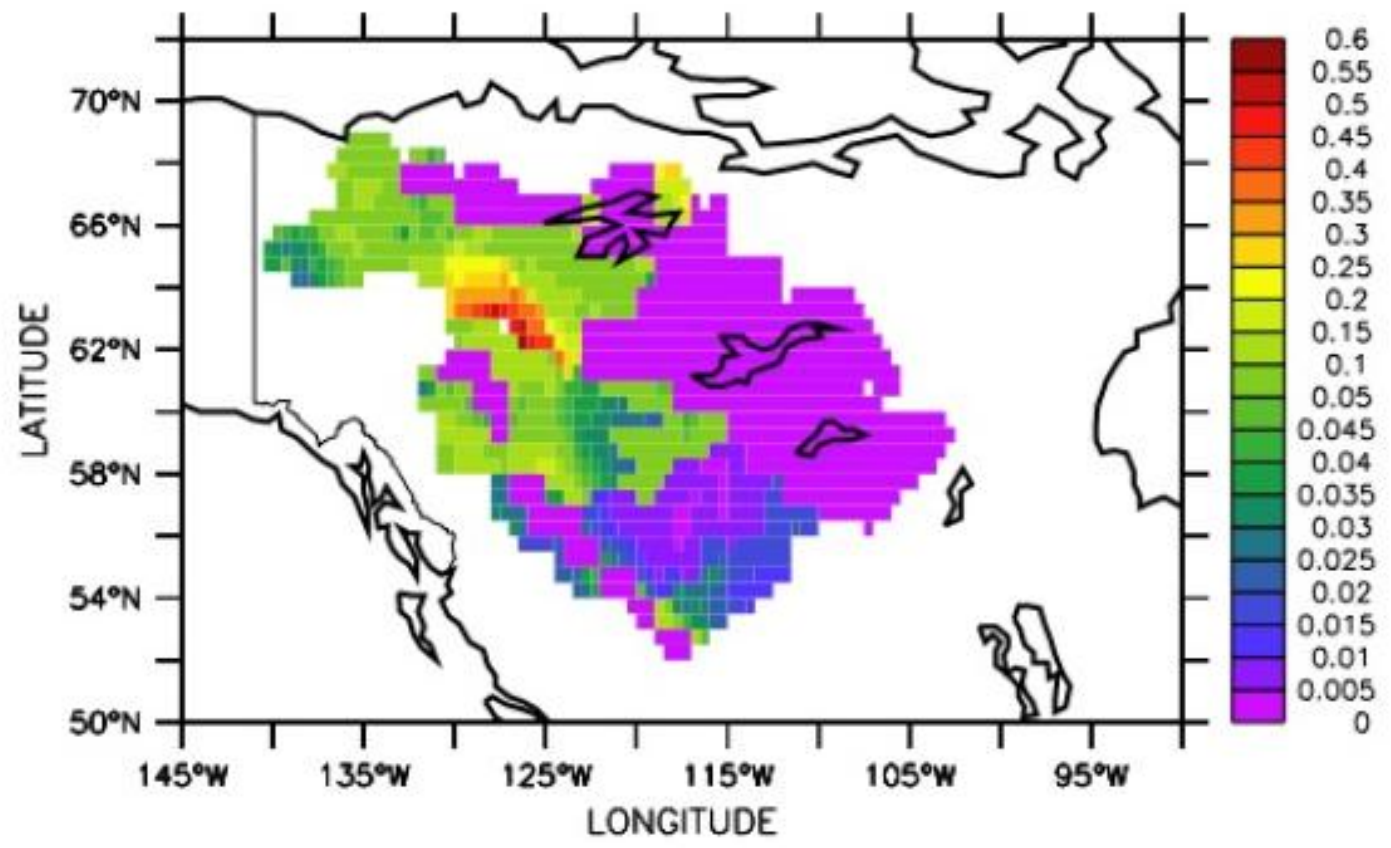

Figure 4 


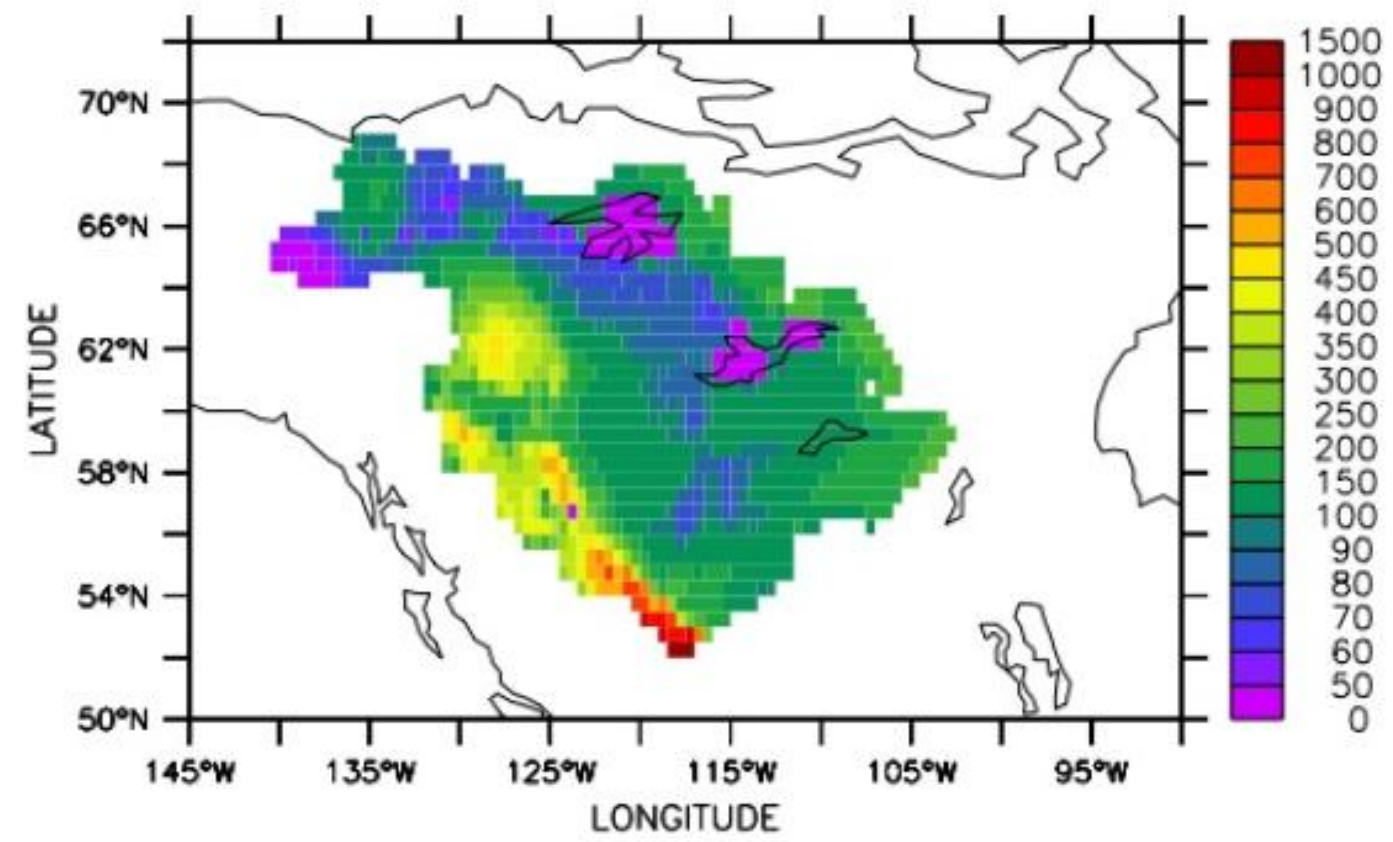

Figure 5 


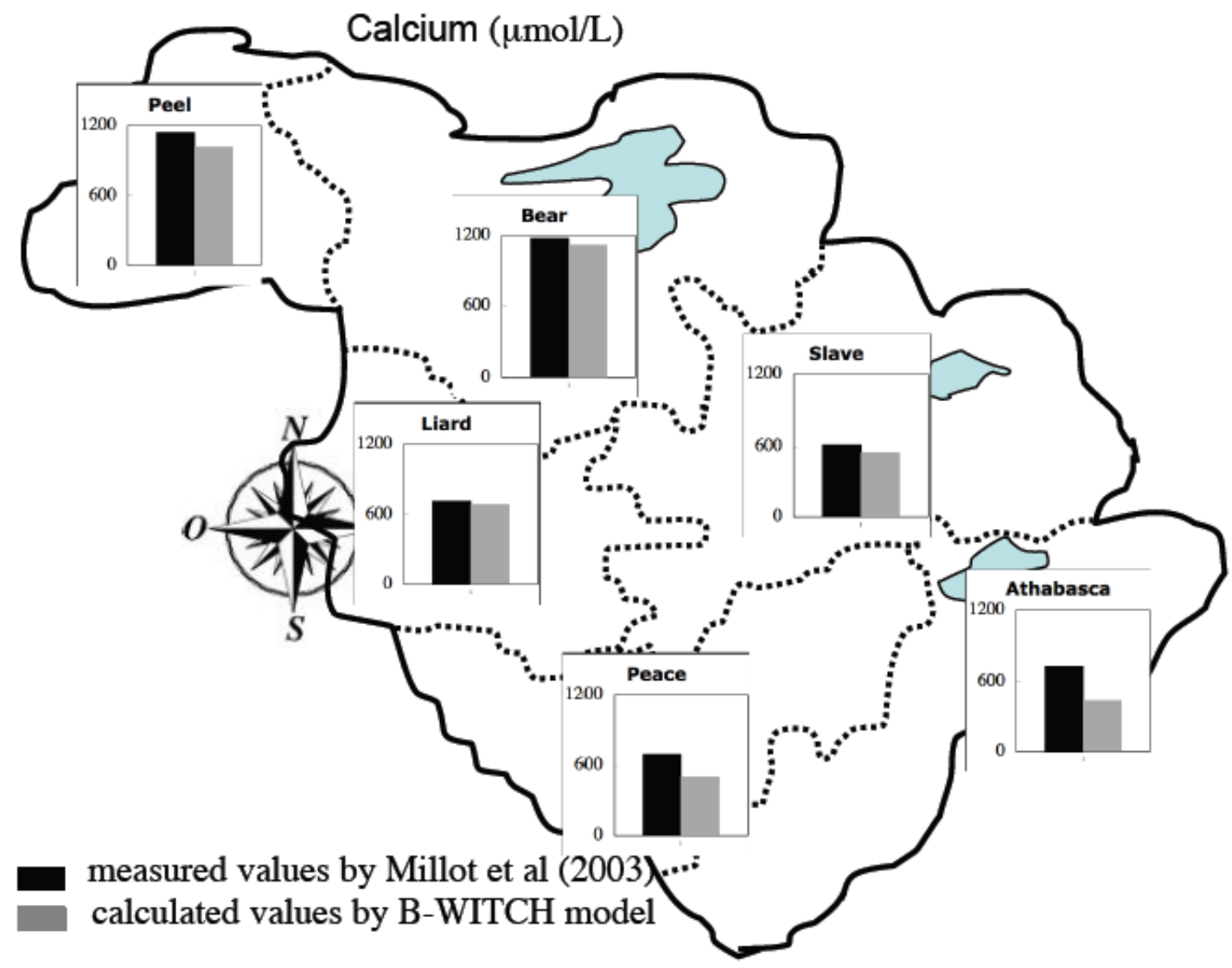

Figure 6a 


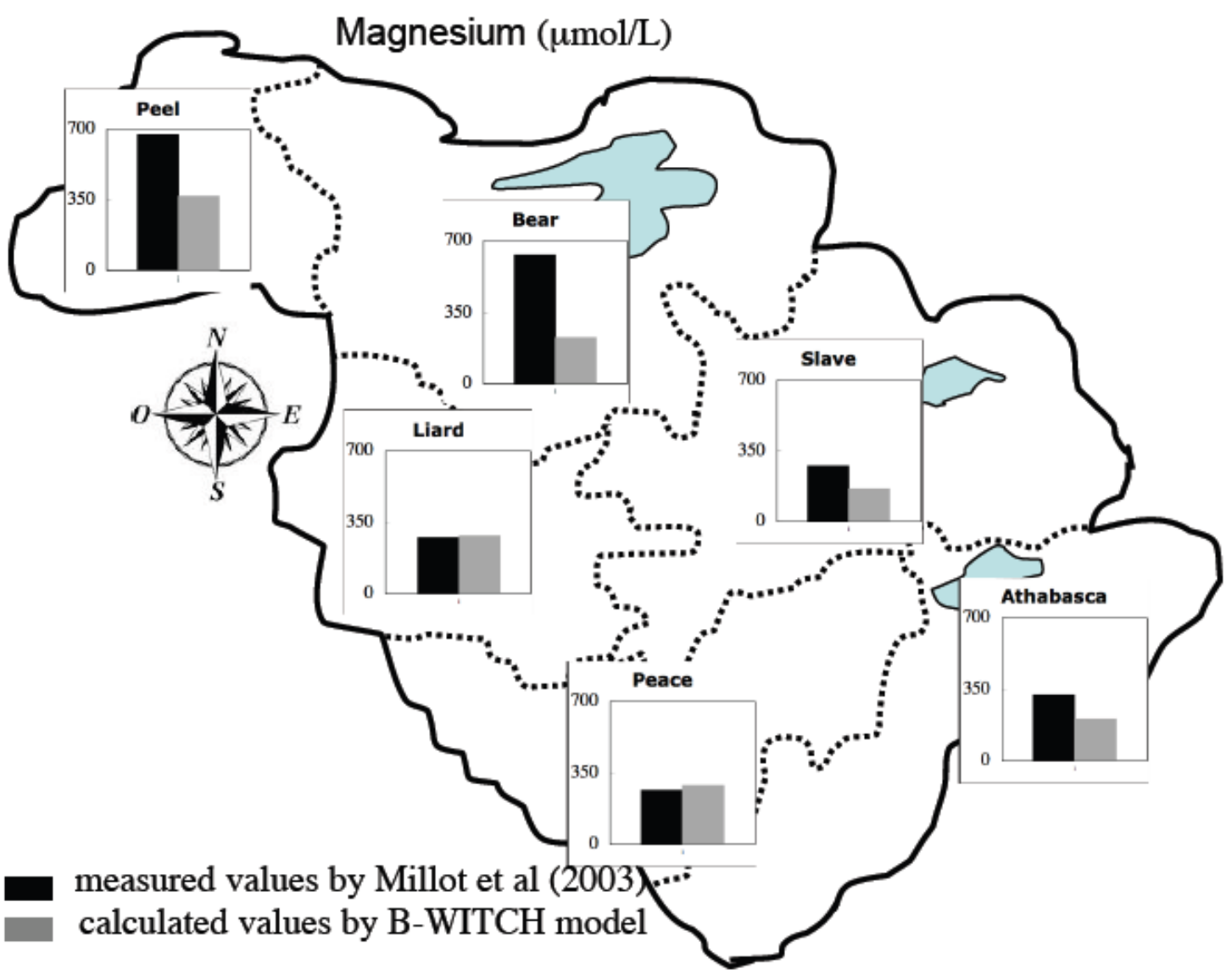

Figure 6b 


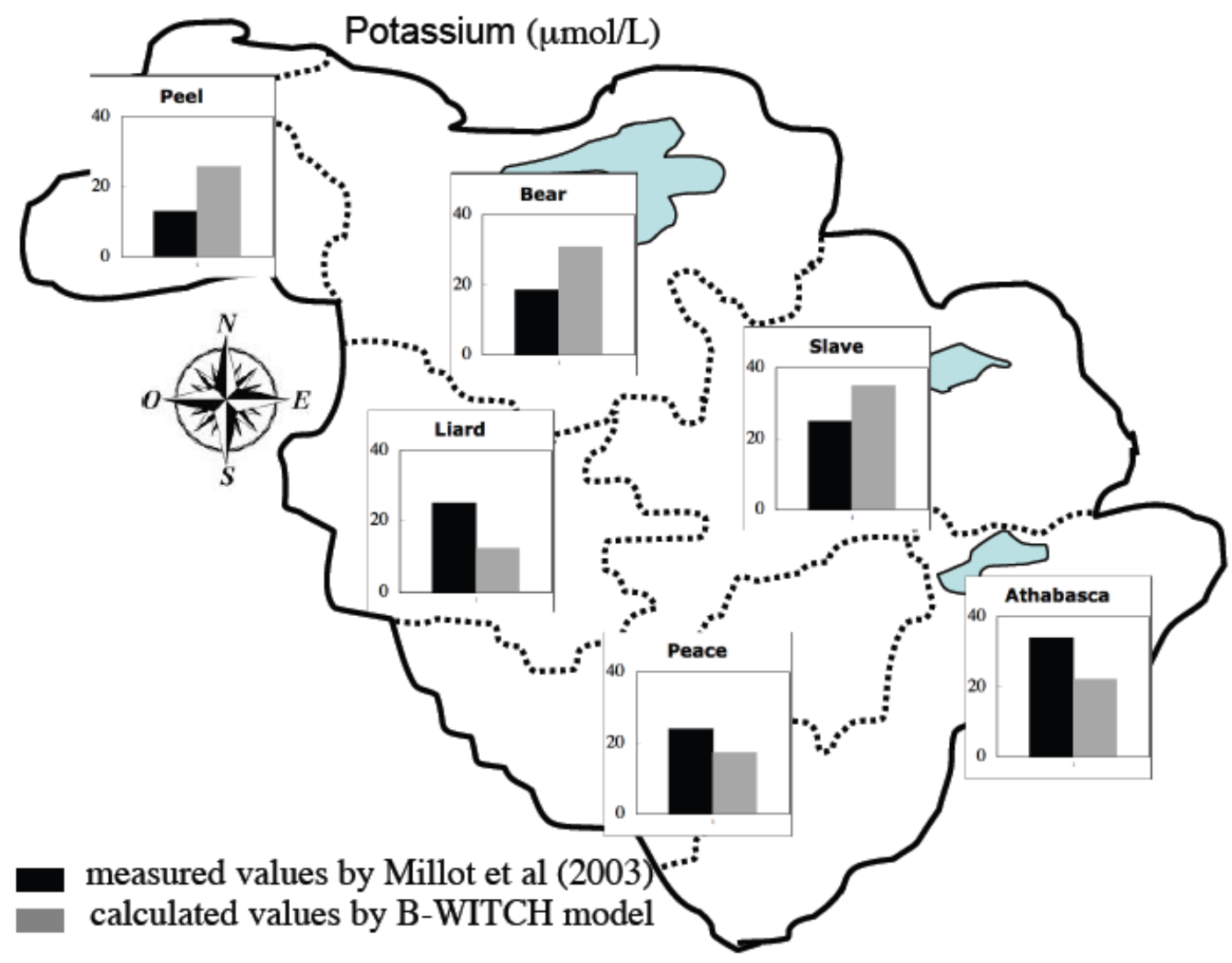

Figure 6c 


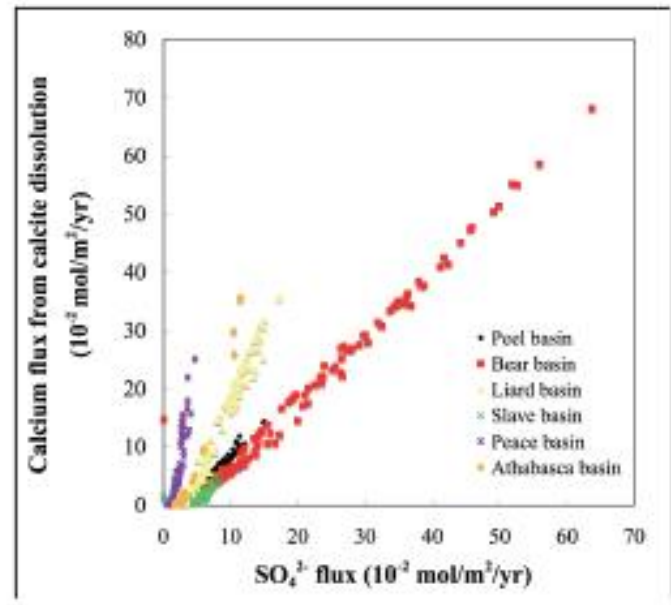

Figure 7a

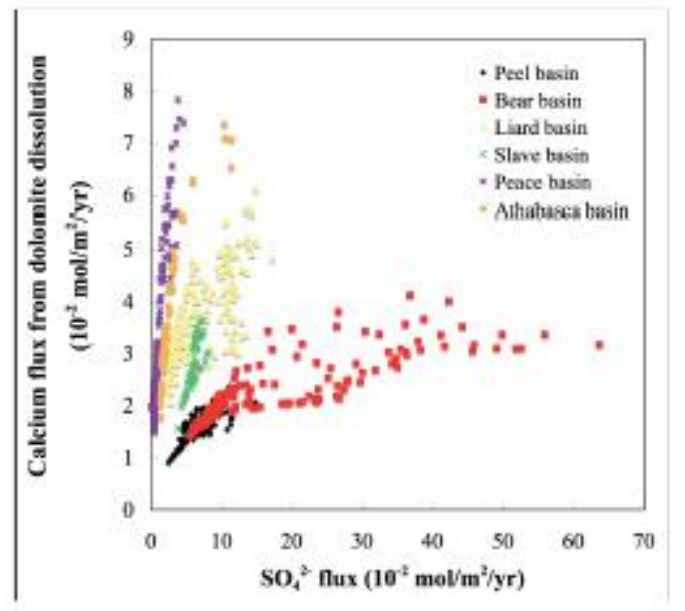

Figure $7 \mathrm{~b}$ 

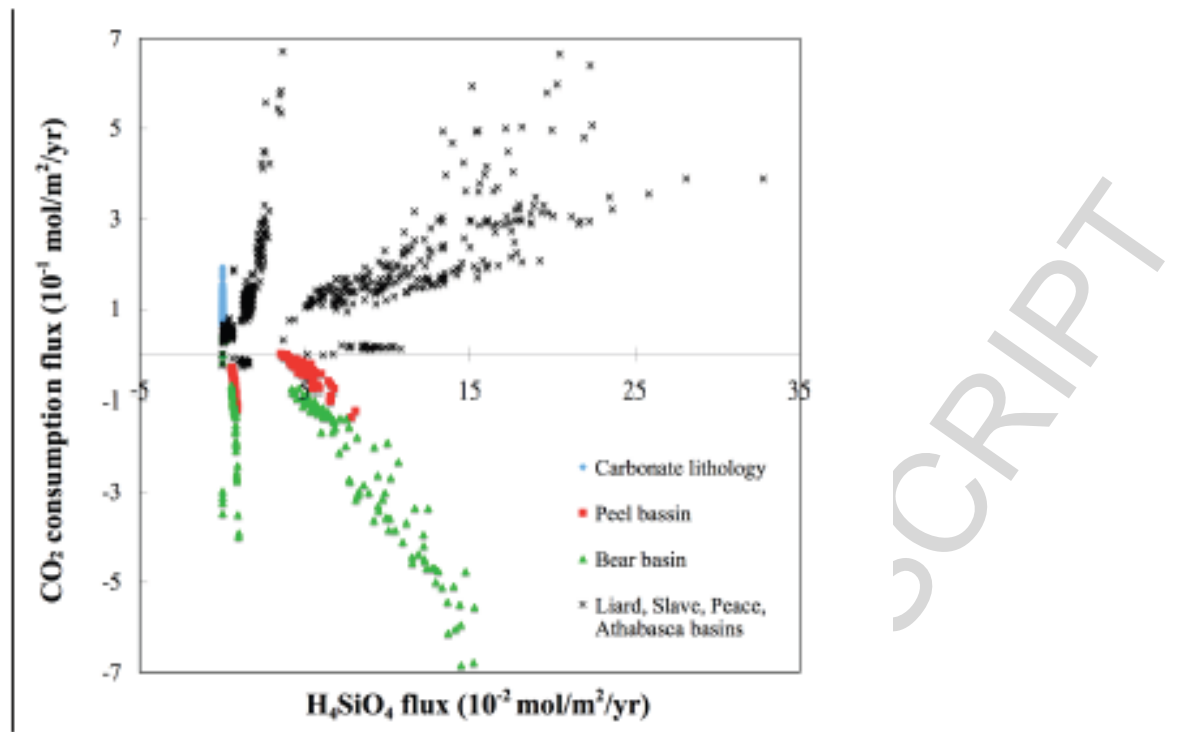

Figure 8 

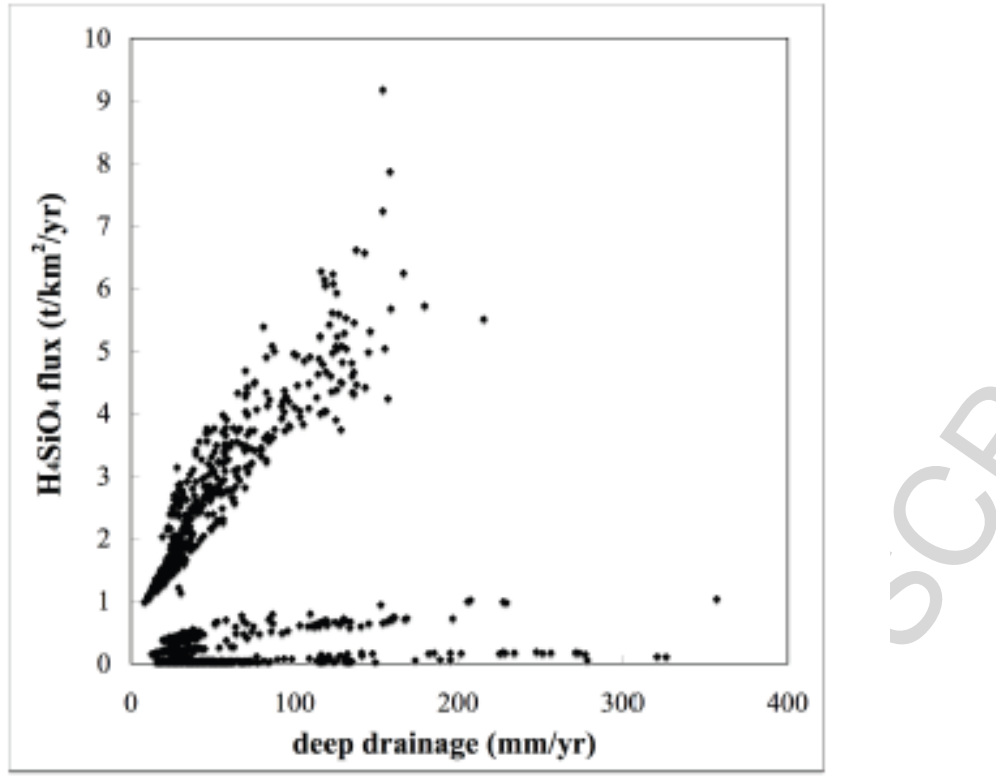

Figure 9 


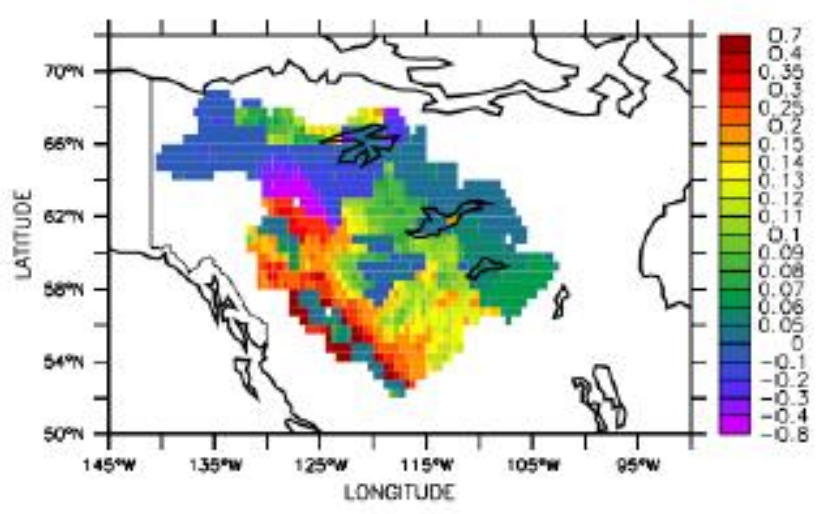

Figure 10 


\section{Highlights}

1) The dissolved silica export is mainly controlled by secondary mineral reactivity in soils

2) The atmospheric $\mathrm{CO}_{2}$ consumption by weathering processes in the Mackenzie river is limited

3) The weathering processes in the Mackenzie watershed act as a source of carbon to the atmosphere

4) The presence of sulfide minerals within a river basin decreases the apparent net consumption of atmospheric $\mathrm{CO}_{2}$ 